\title{
Extreme wave value analysis under uncertainty of climate change scenarios off Iberian Peninsula coast
}

\author{
Bárbara F. V. Vieira*, José L. S. Pinho, Joaquim A. O. Barros \\ Department of Civil Engineering, School of Engineering, University of Minho, \\ Braga 4710-057, Portugal \\ *Corresponding author, barbaravasquezvieira@gmail.com
}

\begin{abstract}
Extreme wave value analysis under uncertainty scenarios was developed to estimate wave climate characteristics at 17 stations in southwestern European coast off the Iberian Peninsula. A comprehensive wave dataset downscaled with the Wave Watch III (WWIII) model by Meteogalicia under MarRisk Project was used considering results of models from the Coupled Model Intercomparison Project 5 (CMIP5). Descriptive statistics for significant wave height (Hs), peak wave period (Tp), and mean and peak wave direction were performed for historical data (1960-2005), and for projected data in two twenty-year time periods under two Representative Concentration Pathway (RCP) scenarios (2026-2045 and 2081-2100). Hs and Tp extreme values for the study area were obtained using the Gumbel, Fréchet and Weibull probability distributions for the 10-, 50-, and 100-year return period. Obtained results showed that: historical Hs values decrease from North to South and are higher than those calculated in any of the RCPs future scenarios; mean Tp values appear to be constant in all stations; and means for peak and mean direction have higher frequency of occurrence in Q4 $\left(270^{\circ}-360^{\circ}\right)$. This study also allowed the computation of $\mathrm{Hs}$ and $\mathrm{Tp}$ values for 100 -year return period, which can be used as design criteria for structural analyses in maritime works.
\end{abstract}

\section{Keywords}

Extreme events, probability distribution, significant wave height, uncertainty, wave climate projections, RCPs scenarios 


\section{Introduction}

The special characteristics of coastal zones including their high population density has greatly increased during the recent decades, which is associated to rapid economic growth and coastward migration (Merkens et al., 2016; Neumann et al., 2015).

Demographic pressure on coastal areas has resulted in significant infrastructure and assets being located at risk-prone areas, increasing exposure and vulnerability to natural hazards along the coast.

Indeed, coastal zones are extremely vulnerable regions with delicate physiographic equilibria, whose ecosystems are highly influenced by Mean Sea Level Rise (MSLR) and related hazards (including erosion, flooding and salt intrusion) that are expected to significantly increase by the end of this century in the absence of major additional adaptation efforts (Callaghan et al., 2020; Cheng and Chen, 2017; Chini et al., 2010; Ding et al., 2013; Feng et al., 2019; Mori et al., 2013; SROCC, 2019; Warner and Tissot, 2012; Xie et al., 2019). The evolution over the past two centuries suggests that the tendency for sea levels rising and consequent coastal erosion will aggravate in the $21^{\text {st }}$ century independently of the considered global warming scenarios (Mase et al., 2013; Mori et al., 2013; Zhang et al., 2004).

Climate change and its undesirable consequences, such as an expected increasing frequency and magnitude of extreme events, generate additional risks to water-related infrastructure, requiring an ever-increasing need for adaptation measures (SROCC, 2019). Special planning and management approaches with a paradigmatic shift from crisis management to risk management (hazard analysis and vulnerability analysis) in a changing environment are required.

Risk management approaches require actual and future projections of wave climates, including storm wave data. For this purpose, application of probability distributions for extreme wave climate data is a usual applied methodology to estimate extreme wave data for the design, operation and maintenance of coastal infrastructures, under uncertainty caused by climate change.

The United Nations Intergovernmental Panel on Climate Change (IPCC) adopted different greenhouse gas concentration trajectories (Representative Concentration Pathway - RCP), to describe different future climates based on the volume of greenhouse gases emitted in the future years. The RCPs are commonly used to assess scientific, technical and socio-economic information concerning climate change, its potential effects and options for adaptation and mitigation (IPCC, 2020).

Predicted change in global mean surface temperature and global MSLR for the mid- and end $21^{\text {st }}$ century (2046-2065 and 2081-2100 averages, respectively), relative to the 1986-2005 period, is strongly dependent on which RCP emission scenario is followed. MSLR is projected to rise between $0.47 \mathrm{~m}(0.32-0.63 \mathrm{~m}$, likely range) (RCP4.5) and $0.63 \mathrm{~m}(0.45-0.82 \mathrm{~m}$, likely range) (RCP8.5) by 2100 (likely range) relative to 19862005 (IPCC, 2014). These sea levels rise will imply the dissipation of wave energy at higher levels in the nearshore that could be exacerbated by eventual aggravation of the extreme wave climates.

The most used descriptor of the wave field is the energy-density spectrum in both frequency and direction of propagation. From this spectrum, most of the parameters 
commonly used for describing wave climate regimes can be derived, namely: the significant wave height, $H_{s}(m)$, the peak wave period, $T_{p}(s)$, the mean wave direction, $\mathrm{D}_{\mathrm{m}}\left({ }^{\circ}\right)$, and the peak wave direction, $\mathrm{D}_{\mathrm{p}}\left({ }^{\circ}\right)$. Three main types of wave data are available: from observation, measurement or simulations. The observation or measurement of waves require personnel and measuring equipment in situ at the time of observation, whereas the simulated wave data are produced and operated by many major meteorological services by making use of numerical wave modelling (WMO, 1998) whose results could be used in the design of coastal structures.

The most widely used variables to design offshore and onshore structures are $\mathrm{H}_{\mathrm{s}}, \mathrm{T}_{\mathrm{p}}$ and $\mathrm{D}_{\mathrm{m}}$ (Capitão and Fortes, 2011; Carvalho and Capitão, 1995; Park et al., 2020; WMO, 1998). Much of the effort given to wave climate studies in recent years has concentrated upon statistical methods for estimating extreme values of these parameters, which require representativeness, consistency, and validity of the collected data to avoid incorrect extrapolation. Gumbel, Fréchet, Weibull, and log-normal value distributions are mostly applied to derive extreme wave data (Capitão and Fortes, 2011; Martucci et al., 2010; Mathiesen et al., 1994; Park et al., 2020; Silva et al., 2008; Wang et al., 2013).

In this study, downscaled wave data of MeteoGalicia (Bio et al., 2020; Pinho et al., 2020) has been used for describing three different wave climates recurring to statistical analysis of $H_{s}, T_{p}, D_{m}$, and $D_{p}$ and in estimating extreme wave data values at 17 selected stations in the Atlantic Ocean off the Iberian Peninsula. This dataset consists of 46 years of historical data (1960-2005) and two twenty-year time periods of RCPs projected data (2026-2045 and 2081-2100).

Although extreme $\mathrm{H}_{\mathrm{s}}$ values computed by wave models could underestimate real values (Dentale et al., 2018; Reale et al., 2020), an extreme value analysis was applied to the datasets defined from the calculation of the $95^{\text {th }}$ percentile of $\mathrm{H}_{\mathrm{s}}$, in order to identify storm waves (Castelle et al., 2015; Goda, 2000; Harley, 2017; Masselink et al., 2014). The 10-, 50-, 100-year return period $\left(\mathrm{T}_{\mathrm{r}}\right)$ of $\mathrm{H}_{\mathrm{s}}$ and $\mathrm{T}_{\mathrm{p}}$ were estimated using the Gumbel, Fréchet, and Weibull distributions. Performance studies applying these three methods concluded that Fréchet and Weibull distributions fit better in estimating extreme values of $\mathrm{H}_{\mathrm{s}}$ (Capitão and Fortes, 2011; Carvalho and Capitão, 1995; Guedes-Soares and Carvalho, 2001; Mathiesen et al., 1994; Piccinini, 2006; Vanem, 2015). Projections from RCP4.5 and RCP8.5 datasets also allow to introduce uncertainty in the results obtained, since the effects of plausible climate change scenarios were considered.

Previous studies in the western coast of Portugal were based on limited time series periods and considered single locations over the region (e.g., Capitão and Fortes, 2011, and Silva et al., 2008 using a time series of 14 years collected at a buoy located at Leixões; and Guedes-Soares and Carvalho, 2001 using a time series of 1 year, collected at a buoy located off port of Sines).

Following those studies, more updated research on extreme value analysis and descriptive statistics on the variability of wave parameters off the Iberian Peninsula, especially at the Portuguese coast, is needed to better understand the wave climate at this region. Based on this recognized gap, this research work intends to address a comprehensive analysis on the wave extremes variability off the Iberian Peninsula under climate change scenarios. 
The comprehensiveness of the wave climate regime database including historical data and projected data for two different greenhouse gases emission RCP4.5 and RCP8.5 scenarios, as well as the statistical methods used, allowed a descriptive statistics and an extreme value analysis of the local wave climate regimes.

Outcomes of this research work include the estimation of extreme values of $\mathrm{H}_{\mathrm{s}}$ and $\mathrm{T}_{\mathrm{p}}$. This information can be a valuable contribution for the establishment of design parameters for coastal engineering projects in the study area and for coastal vulnerability analysis of the Atlantic Iberian coast to climate change.

\section{Study Area and Data Sources}

The Iberian Peninsula (Portugal and Spain) has an Atlantic coastline with approximately $1.300 \mathrm{~km}$ of extension. This energetic coast has been subject to intensive urbanisation and coastward migration associated mainly to tourism, fishing, aquaculture, industry, and port activities. In the last decades, this region has being subject to an erosional process, coastal floods and aquifers salinization as showed in different studies (Álvarez et al., 2020; Baptista et al., 2014; Cherneva et al., 2005; Guedes-Soares and Carvalho, 2001; Pereira and Coelho, 2013; Pinho et al., 2020).

Winter storms are of common occurrence in this region (Gomes et al., 2018; Santos et al., 2018). Due to scarcity of monitoring data, hydrodynamic modelling works have been performed to assess the effect of three categories of storms on water levels at this coast. Ensemble simulations performed by Gomes et al. (2018) estimated a maximum sea level of $2.3 \mathrm{~m}$ for hurricanes and tropical storms, and a maximum sea level of $1.2 \mathrm{~m}$ for tropical depressions (values above mean spring-tide level of $3.75 \mathrm{~m}$ ). The effects of these phenomena combined with storm waves can be associated with wave-overtopping and coastal flooding events with harmful consequences for coastal environments.

In this study the wave climate data (significant wave height, peak period, and wave direction) were obtained from wave datasets downscaled with the Wave Watch III model (WWIII) of Meteogalicia, both for historical and future climates. This model was forced with results of the Model for Interdisciplinary Research On Climate 5 (MIROC5), which is included in the Coupled Model Intercomparison Project 5 (CMIP5) atmospheric/ocean global simulations (Qu et al., 2020; Sperna-Weiland et al., 2016; Vanem, 2017). HP original CMIP5 (MIROC5) results were obtained by properly assimilate ocean and atmospheric observed data as reproduced in Tatebe et al. (2012).

Within the scope of the MarRisk project (Bio et al., 2020; Pinho et al., 2020), the Meteogalicia WWIII model was forced with CMIP5 data, allowing this way to downscale model results for 17 stations off the western coast of Iberian Peninsula. Figure 1 presents the study area and the location of those stations. 


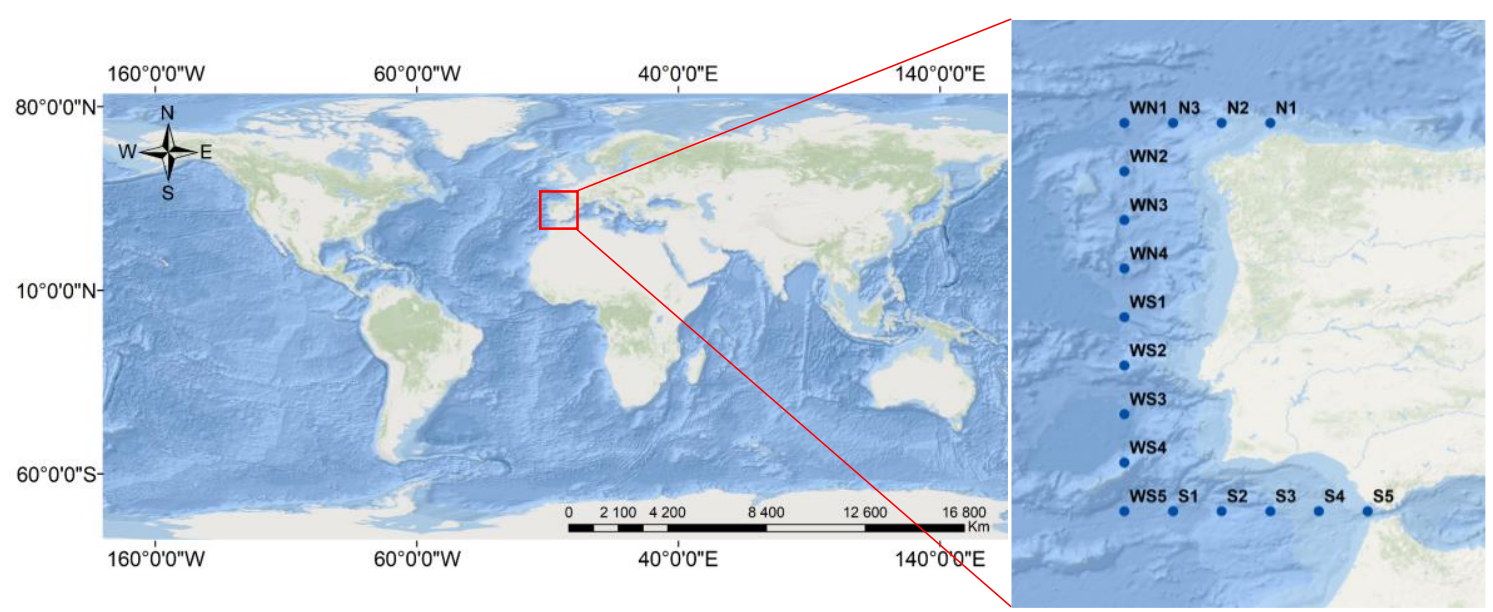

Figure 1. Study area with location of the 17 stations around the Iberian Peninsula.

The spectral data resulting from the WWIII model runs was provided for the 17 selected stations, which are properly numbered and aggregated according their location (North, West, and South) in relation to the Iberian Peninsula (Table 1).

Table 1. Coordinates of the study selected stations.

\begin{tabular}{cccc}
\hline Station & Longitude & Latitude & Depth related to mean sea level (m) \\
\hline $\mathbf{N 1}$ & -8.00 & 44.00 & $-206,60$ \\
\hline $\mathbf{N} 2$ & -9.00 & 44.00 & $-1199,45$ \\
\hline $\mathbf{N 3}$ & -10.00 & 44.00 & $-4971,26$ \\
\hline $\mathbf{W N 1}$ & -11.00 & 44.00 & $-4998,02$ \\
\hline $\mathbf{W N 2}$ & -11.00 & 43.00 & $-2490,85$ \\
\hline $\mathbf{W N 3}$ & -11.00 & 42.00 & $-2734,10$ \\
\hline $\mathbf{W N 4}$ & -11.00 & 41.00 & $-3890,95$ \\
\hline $\mathbf{W S 1}$ & -11.00 & 40.00 & $-4723,50$ \\
\hline $\mathbf{W S 2}$ & -11.00 & 39.00 & $-3333,70$ \\
\hline $\mathbf{W S 3}$ & -11.00 & 38.00 & $-5018,40$ \\
\hline $\mathbf{W S 4}$ & -11.00 & 37.00 & $-2533,70$ \\
\hline $\mathbf{W S 5}$ & -11.00 & 36.00 & $-4870,75$ \\
\hline S1 & -10.00 & 36.00 & $-4542,95$ \\
\hline S2 & -9.00 & 36.00 & $-3700,45$ \\
\hline S3 & -8.00 & 36.00 & $-1522,45$ \\
\hline S4 & -7.00 & 36.00 & $-809,55$ \\
\hline S5 & -6.00 & 36.00 & $-161,93$ \\
\hline
\end{tabular}

WWIII spectral data results comprises historical wave climate data, as well as wave climate projections based on the RCPs climate change scenarios. The CMIP5 selected model used to simulate climate change scenarios was possible, since it have yielded reasonable calibration results using a sound 46 years wave climate data.

Results obtained from the application of recently developed phase 6 of CMIP (CMIP6) demonstrated similar outcomes as those obtained with CMIP5 (McKenna et al., 2020; Plecha and Soares, 2020; Zhu et al., 2020). While there was a significant improvement 
from CMIP3 to CMIP5 in simulating mean sea level, the same was not verified from CMIP5 to CMIP6. Major differences are mainly found in middle-to-high latitudes in the Southern Hemisphere. Moreover, regarding ocean dynamic sea level projections, a similarity of results was also verified between CMIP5 and CMIP6 (Lyu et al., 2020).

The used data includes five different wave climate scenarios: one for the historical period, HP, (1960-2005), and four projections under the climate change scenarios RCP4.5_mid (2026-2045), RCP4.5_end (2081-2100), RCP8.5_mid (2026-2045), and RCP8.5_end (2081-2100). The historical period includes 46 years of data, while the projection periods comprise two twenty-year time periods (for the mid and end periods of $21^{\text {st }}$ century) which give a reasonably extensive datasets enabling reliable extrapolations for wave climate regimes analysis (Capitão and Fortes, 2011; Park et al., 2020; Wang et al., 2016; Wang and Swail, 2001).

The WWIII spectral information files, in NetCDF format, are divided into 1512 files making up 12.9 GB of disk space. Each NetCDF file contains spectral information for one month and the temporal resolution of the data is 3 hours. Table 2 shows the structure of the information used in each of the NetCDF files.

Table 2. List of variables used in each WWIII NetCDF file.

\begin{tabular}{clcc}
\hline Variable & Description & Type & Unit \\
\hline direction & Sea surface wave direction & $1 \mathrm{D}$ & degree \\
\hline Dpt & Depth & 2D & $\mathrm{m}^{-1}$ \\
\hline Efth & Sea surface wave directional variance spectral density & 2D & $\mathrm{m}^{2} \mathrm{~s} \mathrm{rad}^{-1}$ \\
\hline frequency & Frequency of centre band & $1 \mathrm{D}$ & $\mathrm{s}^{-1}$ \\
\hline frequency1 & Frequency of lower band & $1 \mathrm{D}$ & $\mathrm{s}^{-1}$ \\
\hline frequency2 & Frequency of upper band & $1 \mathrm{D}$ & $\mathrm{s}^{-1}$ \\
\hline latitude & Latitude & 2D & Degree North \\
\hline longitude & Longitude & 2D & Degree East \\
\hline station & Station id & 1D & - \\
\hline station_name & Station name & - & - \\
\hline time & Julian day & 1D & day \\
\hline
\end{tabular}

\section{Methodology}

\subsection{Methods for extreme wave data analysis under uncertainty}

Waves extremes eventually exacerbated by climate change increase the magnitude of hazards to coastal infrastructure, either expressed in terms of frequency or severity (IPCC, 2014; Marone et al., 2017; Pinho et al., 2020). The use of probability models is of paramount importance for determining wave climate regimes and predicting intensity and duration of extreme events occurrences. Climate projections for the $21^{\text {st }}$ century are inherently uncertain since there is low confidence in projections of many aspects of climate phenomena that influence regional climate change (Sun et al., 2017). The rate of future global warming effects depends on unpredictable natural influences on climate like volcanic eruptions, as well as on greenhouse gas concentrations due to anthropogenic activities (IPCC, 2020). 
Uncertainties arising from climate change scenarios may question the validity of future projections based on data collected in the past. Some authors claim that "stationarity is dead" stating that climate change undermines basic assumption that historically has facilitated management of water resources and risks (Milly et al., 2008). However, this philosophical approach has been contradicted by many authors who consider that the process of climate change is accepted as a 'certainty' and value the need for hydrological predictions based on assumptions that should include stationarity (Montanari and Koutsoyiannis, 2014). In line with these authors, this research work follows a pragmatic approach in predicting extreme wave climate regimes based on the exploitation of simulated datasets generated by numerical models applied to historical and to RCPs scenarios.

An extensive temporal and spatial wave database was used to effectively deal with climate change uncertainty. The usual parameter chosen to estimate the severest conditions likely to be experienced by coastal infrastructures is either the 50- or the 100year return period of wave height $\left(\mathrm{H}_{\mathrm{s}}\right)$, where the $\mathrm{N}$-year return period is defined as that which is exceeded on average once every $\mathrm{N}$ years (WMO, 1998). This parameter is very important in coastal vulnerabilities analysis and coastal defence solutions design. However, for a complete description of extreme conditions, information on wave peak period $\left(T_{p}\right)$ is also required. This research work has concentrated upon methods for estimating extreme values of $\mathrm{H}_{\mathrm{s}}$, and the correspondent $\mathrm{T}_{\mathrm{p}}$.

Techniques for extreme value analysis consist of adjusting a theoretical probability distribution function to the function of the estimated distribution of a sample, in order to describe a certain random variable behaviour (Silva et al., 2008). Several methods for estimating extreme wave data and to define the local wave climates are available elsewhere (Karian and Dudewicz, 2000; Naghettini and Pinto, 2007; Nascimento, 2009; Park et al., 2020; Sansigolo, 2008; Thevasiyani and Perera, 2014; Urošev et al., 2016).

For this purpose, different probability distributions have been applied: Gumbel (Cotta et al., 2016; Silva et al., 2008); Gumbel and Weibull (Mathiesen et al., 1994; Park et al., 2020); Gumbel, Fréchet and Weibull (Capitão and Fortes, 2011; Carvalho and Capitão, 1995; Goda, 2000; Sansigolo, 2008).

In order to assess the relative performance of different methods, this research applied three generalized extreme value (GEV) probability distributions (Gumbel, Fréchet, and Weibull) to estimate the extreme values of the $\mathrm{H}_{\mathrm{s}}$ and the associated $\mathrm{T}_{\mathrm{p}}$ for the 10-, 50-, 100 -year return period. The application of these probability distributions required a previous selection of annual maxima $\mathrm{H}_{\mathrm{s}}$ values for all stations. Usually, two different methods (annual maxima and peaks-over-threshold) are widely used in extreme value analysis. According to Goda (2000), the annual maxima approach should be used for databases covering more than 20 years, while for shorter records of extreme data the peaks-over-threshold seems to be a more reliable method. For methodological coherence reasons, in this study the annual maxima method was selected for the 46-year span HP data and for the two 20-year span RCPs scenarios data. These GEV probability distribution methods consider that the distribution of maxima of $n$ values are asymptotic with increasing the number $n$, and this is the reason for their usual application on extreme meteorological events with good results. 
Extreme value analysis was conducted after transforming the extreme value distributions from the probability distribution function form to the cumulative distribution function (CDF) form for the convenience of computation. Equations (1) to (3) show the CDF of Gumbel, Fréchet and Weibull distributions (Vivekanandan, 2012):

$F(X)=e^{-e^{-\left(\frac{X-\alpha_{G}}{\beta_{G}}\right)}}, \beta_{G}>0$ and $-\infty<X<\infty$ (for Gumbel)

$F(X)=e^{-\left(\frac{X}{\beta_{F}}\right)^{\left(-\lambda_{F}\right)}}, \beta_{F}>0$ and $-\infty<X<\infty$ (for Fréchet)

$F(X)=e^{-\left(\frac{X}{\beta_{W}}\right)^{\lambda},}, \beta_{W}>0$ and $-\infty<X<\infty$ (for Weibull)

where $X$ is the random variable under consideration $\left(\mathrm{H}_{\mathrm{s}}, \mathrm{T}_{\mathrm{p}}\right) ; \alpha_{G}$ and $\beta_{G}$ are the location and scale parameters of the Gumbel distribution; $\beta_{F}, \lambda_{F}$ and $\beta_{W}, \lambda_{W}$ are the scale and shape parameters of Fréchet and Weibull distributions, respectively.

The inverse first-order reliability method (I-FORM), as proposed by Winterstein et al. (1993), was applied to calculate the exceedance probability according to the Equation (4):

$\left.P=S\left(X_{i}\right)=i /(N+1), P \in\right] 0,1[$

where $P$ is the exceedance probability of $X ; N$ is the total number of samples; $i$ $(i=1, \ldots, N)$ is the number of sample values for which any variable value $x \leq X_{i}$.

The method of fitting the chosen distribution was based on the application of the probability plot correlation coefficient technique (Filliben, 1975). The use of this graphical technique requires the computation of the percent point function, which is the inverse of the cumulative distribution function. The formulae for the percent point function $\mathrm{G}(\mathrm{P})$ expressing graphical coordinates that fit the Gumbel, Fréchet, and Weibull distributions are presented in Table 3.

Table 3. Percent point functions for the selected probability distributions.

\begin{tabular}{ccc}
\hline \multirow{2}{*}{ Probability Distribution } & \multicolumn{2}{c}{ Percent Point Function Plotting } \\
\cline { 2 - 3 } & x-axis coordinate & y-axis coordinate \\
\hline Gumbel & $X_{i}$ & $G_{g}(P)=-\ln [\ln (1 / P)]$ \\
\hline Fréchet & $\ln \left(X_{i}\right)$ & $G_{f}(P)=-\ln [-\ln (P)]$ \\
\hline Weibull & $\ln \left(X_{i}\right)$ & $G_{w}(P)=\ln [\ln [1 /(1-P)]]$ \\
\hline
\end{tabular}

Equation 5 was employed to estimate the 10-, 50-, 100-year return period of extreme wave data, which gives the correspondence between the exceedance probability, $P$, and the return period, $T_{r}$ (Silva et al., 2008).

$T_{r}=\frac{1}{1-P}$

The chosen distribution function is then fitted by approximating a linear function through the plotted values by the least squares method. The parameters were obtained 
using the slopes and y-intercept values when the coefficient of determination $\left(\mathrm{R}^{2}\right)$ value was the highest.

\subsection{Descriptive statistics of the local wave regimes}

A comprehensive statistical analysis was performed to determine the characteristics of wave regimes for each of the stations located off the Iberian Peninsula coastal zone. The downscaled CMIP5 results were used in the construction of the following five wave climate regimes datasets: (i) HP; (ii) RCP4.5_mid and RCP4.5_end; and RCP8.5_mid and RCP8.5_end. A diagrammatic scheme that shows the followed descriptive statistics analysis is presented in Figure 2.

A statistical analysis was performed for: (i) the complete wave dataset; and (ii) for a storm sub-dataset, obtained from the application of a criterion based on $\mathrm{H}_{\mathrm{s}}$ values exceeding the 0.95 quantile as storm definition (a peaks-over-threshold method where a set of values above a certain threshold level are selected). This methodology was applied to obtain characteristics of wave climate evolution with special focus on storms due to the relevance of extreme phenomena.

Wave dataset served as the basis for determining the mean values for $H_{s}, T_{p}, D_{m}$, and $D_{p}$ (independent variables); the maximum values for $\mathrm{H}_{s}$; and the 0.95 quantile of $\mathrm{H}_{\mathrm{s}}$

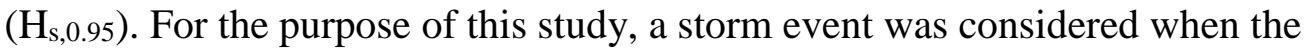
significant wave height exceeds $\mathrm{H}_{\mathrm{s}, 0.95}$ (Castelle et al., 2015; Harley, 2017, Masselink et al., 2014). From the calculation of $\mathrm{H}_{\mathrm{s}, 0.95}$, a sub-dataset was obtained with mean storm values. Based on this sub-dataset, descriptive statistics were obtained for peak $\mathrm{H}_{\mathrm{s}}, \mathrm{T}_{\mathrm{p}}$, $\mathrm{D}_{\mathrm{m}}$, and $\mathrm{D}_{\mathrm{p}}$. Moreover, for the storm event data, a frequency analysis was also conducted to analyse which $\mathrm{D}_{\mathrm{m}}$ and $\mathrm{D}_{\mathrm{p}}$ quadrants are more frequent at each station. An analysis of the maximum, and mean storms duration, as well as the number of storms registered and the mean storms per year at each station was also performed.

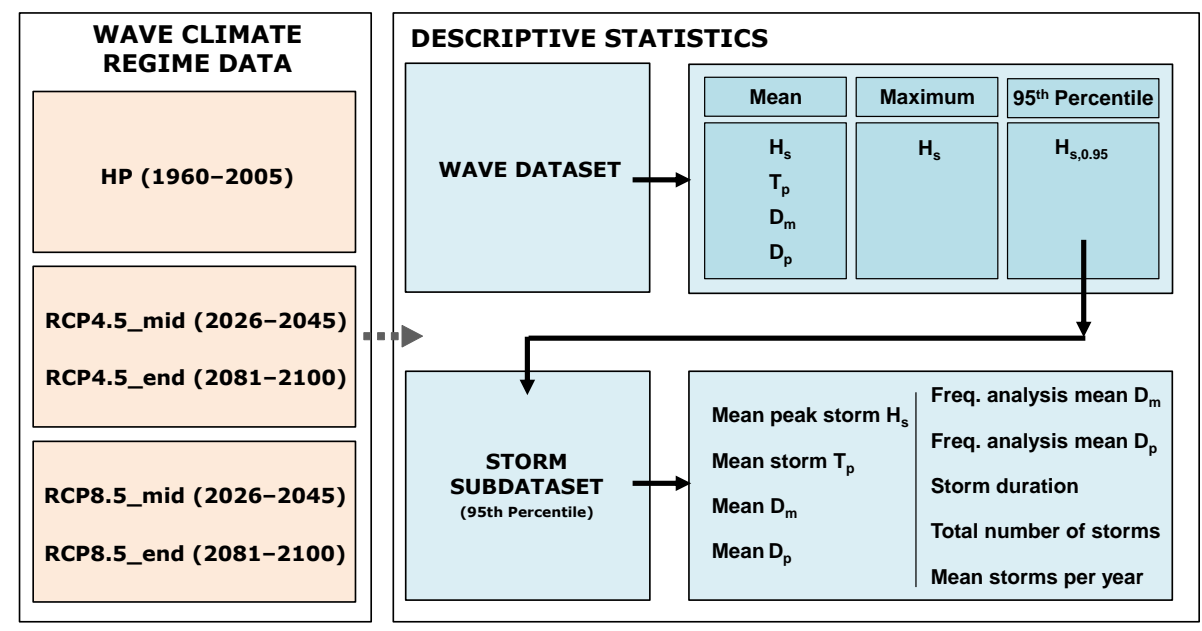

Figure 2. Methodological scheme applied for descriptive statistics.

\subsection{Extreme value analysis of wave climate regimes}

The extreme value analysis of storm sub-dataset was performed to estimate the 10-, 50-, 100-year return period of $\mathrm{H}_{\mathrm{s}}$ and $\mathrm{T}_{\mathrm{p}}$ for all stations off the Iberian Peninsula coastal 
zone, covering the five wave climates regimes. The method employed followed two sequential steps: (i) the wave regime historical data for the period of 1960-2005 was selected and the Gumbel, Fréchet, and Weibull GEV probability distributions were used comparing which of them give better fitting of extreme wave regime values, by calculating the respective coefficient of determination $\left(\mathrm{R}^{2}\right)$; (ii) selected GEV probability distributions (Fréchet for $\mathrm{H}_{\mathrm{s}}$, and Weibull for $\mathrm{T}_{\mathrm{p}}$, based on the best fitting method) were applied to estimate the extreme values for two time periods (2026-2045 and 2081-2100) under the RCP4.5 and RCP8.5 climate change scenarios. Figure 3 depicts the scheme adopted in estimating the extreme values for wave regimes.

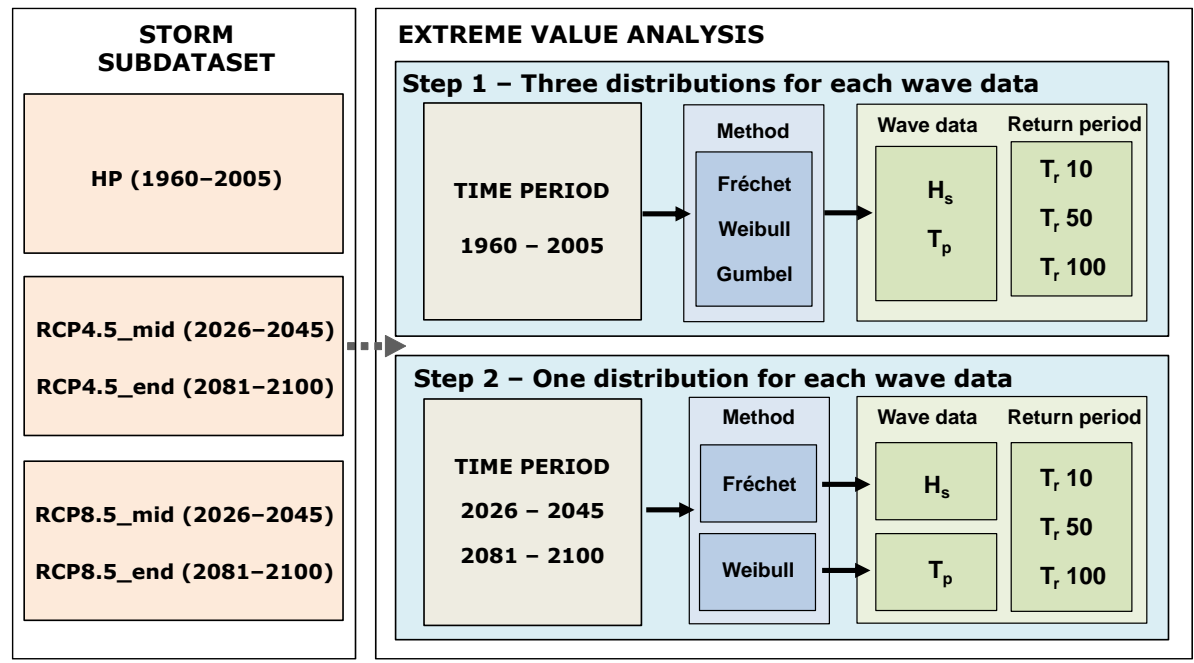

Figure 3. Methodological scheme applied for extreme value analysis.

\section{Results and discussion}

At southwestern coast of Iberian Peninsula variable wave climatic regimes are notorious depending on the different climate scenarios and on the geographical location. Descriptive statistics for complete wave dataset and storm sub-dataset, as well as extreme value analysis of $\mathrm{H}_{\mathrm{s}}$ and $\mathrm{T}_{\mathrm{p}}$ (for historical and projected data) have been performed for all analysed stations. Obtained results are presented in a graphical form supported by tables that include wave climate data numerical values. Comparison with existing studies and proposal of extreme values for coastal engineering design are also discussed.

The stations were clustered into four groups as presented in Table 4. Geo-location of the stations and the homogeneity of the obtained results served as criteria to define the station groups: N for North stations; WN and WS for West stations; and S for South stations.

Table 4. Station groups.

\begin{tabular}{cc}
\hline Station Group & Stations \\
\hline $\mathrm{N}$ & $\mathrm{N} 1 ; \mathrm{N} 2 ; \mathrm{N} 3$ \\
\hline $\mathrm{WN}$ & $\mathrm{WN} 1 ; \mathrm{WN} 2 ; \mathrm{WN} 3 ; \mathrm{WN} 4$ \\
\hline $\mathrm{WS}$ & $\mathrm{WS} 1 ; \mathrm{WS} 2 ; \mathrm{WS} 3 ; \mathrm{WS} 4 ; \mathrm{WS} 5$ \\
\hline $\mathrm{S}$ & $\mathrm{S} 1 ; \mathrm{S} 2 ; \mathrm{S} 3 ; \mathrm{S} 4 ; \mathrm{S} 5$ \\
\hline
\end{tabular}


4.1. Descriptive statistics: complete wave dataset

Main descriptive statistical results for mean $\mathrm{H}_{\mathrm{s}}, \mathrm{H}_{\mathrm{s}, 0.95}$, maximum $\mathrm{H}_{\mathrm{s}}$, mean $\mathrm{T}_{\mathrm{p}}$, mean $\mathrm{D}_{\mathrm{m}}$ and mean $\mathrm{D}_{\mathrm{p}}$ values for wave dataset are presented in a graphical form in Figure 4. 

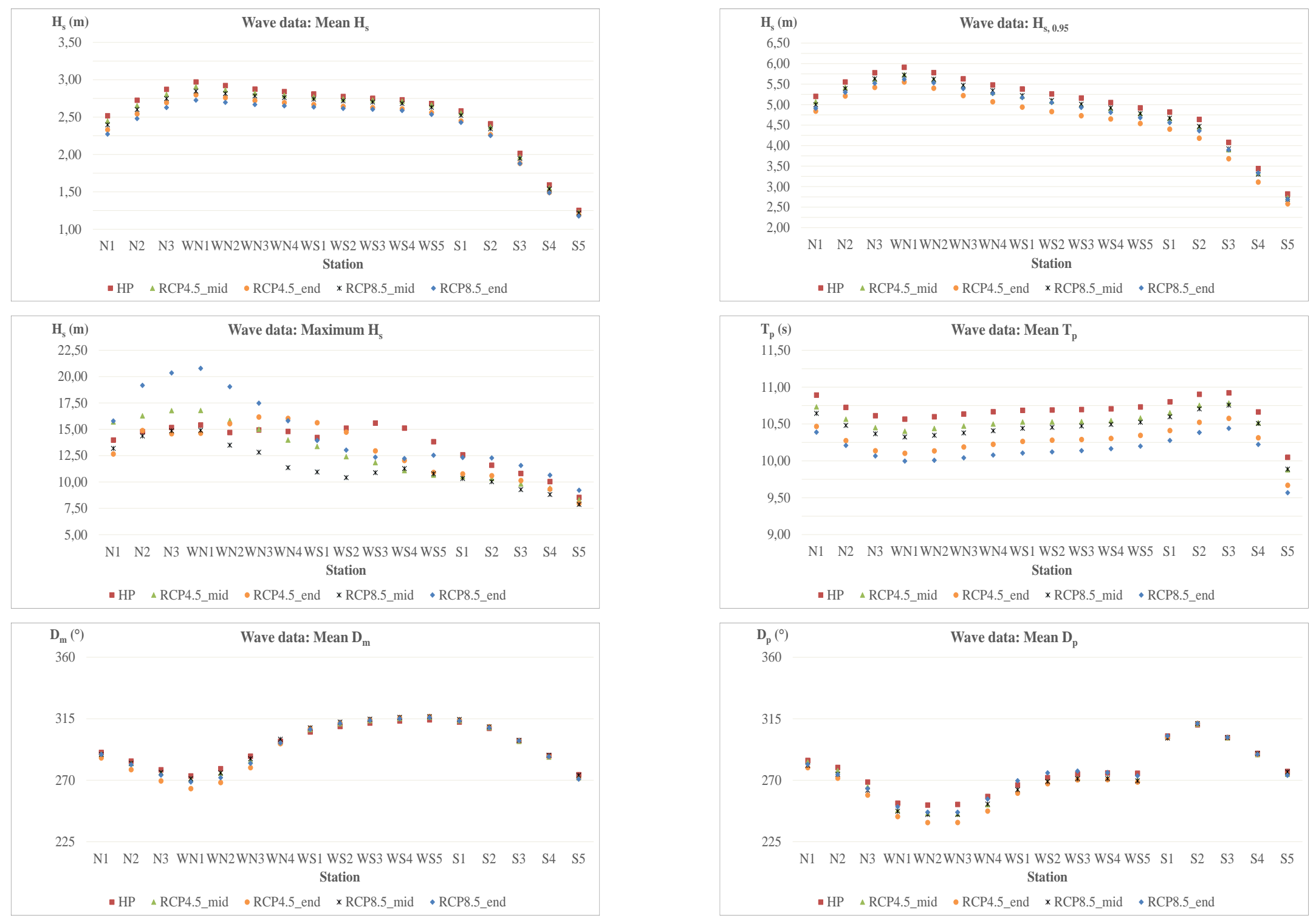

Figure 4. Mean $\mathrm{H}_{\mathrm{s}}, \mathrm{H}_{\mathrm{s}, 0.95}$, maximum $\mathrm{H}_{\mathrm{s}}$, mean $\mathrm{T}_{\mathrm{p}}$, mean $\mathrm{D}_{\mathrm{m}}$ and mean $\mathrm{D}_{\mathrm{p}}$ values for wave dataset under five wave climate regime scenarios. 
Results for wave dataset are organized in Table 5, where minimum and maximum values for each station group for the five wave climate regimes are presented.

Table 5. Descriptive statistics results for the local wave regime using wave dataset from CMIP5.

\begin{tabular}{|c|c|c|c|c|c|c|}
\hline \multirow{2}{*}{$\begin{array}{l}\text { Wave } \\
\text { data }\end{array}$} & \multirow{2}{*}{$\begin{array}{l}\text { Station } \\
\text { Group }\end{array}$} & \multicolumn{5}{|c|}{ Wave climate regime scenario } \\
\hline & & HP & RCP4.5_mid & RCP4.5_end & RCP8.5_mid & RCP8.5_end \\
\hline \multirow{4}{*}{$\begin{array}{l}\text { Mean } H_{s} \\
\quad(\mathrm{~m})\end{array}$} & $\mathbf{N}$ & $2.52-2.87$ & $2.45-2.80$ & $2.33-2.69$ & $2.40-2.75$ & $2.27-2.63$ \\
\hline & $\mathbf{W N}$ & $2.84-2.97$ & $2.79-2.91$ & $2.69-2.80$ & $2.76-2.85$ & $2.65-2.73$ \\
\hline & WS & $2.68-2.81$ & $2.66-2.77$ & $2.56-2.67$ & $2.63-2.74$ & $2.54-2.63$ \\
\hline & $\mathbf{S}$ & $1.25-2.58$ & $1.23-2.56$ & $1.19-2.45$ & $1.22-2.52$ & $1.18-2.43$ \\
\hline \multirow{4}{*}{$\mathbf{H}_{\mathrm{s}, 0.95}(\mathrm{~m})$} & $\mathbf{N}$ & $5.20-5.78$ & $5.07-5.62$ & $4.84-5.42$ & $5.00-5.63$ & $4.91-5.52$ \\
\hline & $\mathbf{W N}$ & $5.48-5.91$ & $5.30-5.73$ & $5.07-5.55$ & $5.34-5.72$ & $5.27-5.62$ \\
\hline & $\mathbf{W S}$ & $4.92-5.38$ & $4.78-5.20$ & $4.54-4.94$ & $4.78-5.22$ & $4.68-5.17$ \\
\hline & $\mathbf{S}$ & $2.82-4.82$ & $2.73-4.66$ & $2.58-4.40$ & $2.69-4.67$ & $2,69-4,56$ \\
\hline \multirow{4}{*}{$\begin{array}{c}\text { Max. } H_{s} \\
(\mathbf{m})\end{array}$} & $\mathbf{N}$ & $13.98-15.17$ & $15.70-16.77$ & $12.66-14.88$ & $13.19-14.86$ & $15.79-20.35$ \\
\hline & $\mathbf{W N}$ & $14.70-15.41$ & $13.99-16.79$ & $14.63-16.17$ & $11.36-14.90$ & $15.81-20.74$ \\
\hline & WS & $13.82-15.59$ & $10.66-13.37$ & $10.91-15.63$ & $10.42-11.28$ & $12.22-13.95$ \\
\hline & $\mathbf{S}$ & $8.54-12.58$ & $8.32-10.51$ & $7.97-10.77$ & $7.87-10.33$ & $9.22-12.32$ \\
\hline \multirow{4}{*}{$\underset{(\mathbf{s})}{\operatorname{Mean} \mathbf{T}_{\mathbf{p}}}$} & $\mathbf{N}$ & $10.61-10.89$ & $10.45-10.73$ & $10.14-10.47$ & $10.37-10.65$ & $10.07-10.39$ \\
\hline & $\mathbf{W N}$ & $10.57-10.67$ & $10.40-10.50$ & $10.10-10.23$ & $10.32-10.41$ & $10.00-10.08$ \\
\hline & WS & $10.69-10.73$ & $10.53-10.58$ & $10.27-10.35$ & $10.44-10.53$ & $10.11-10.20$ \\
\hline & $\mathbf{S}$ & $10.05-10.92$ & $9.88-10.78$ & $9.67-10.58$ & $9.89-10.76$ & $9.57-10.44$ \\
\hline \multirow{4}{*}{$\begin{array}{c}\text { Mean } D_{m} \\
\left(^{\circ}\right)\end{array}$} & $\mathbf{N}$ & $278-290$ & $275-289$ & $269-286$ & $276-289$ & $274-289$ \\
\hline & $\mathbf{W N}$ & 273-299 & $271-298$ & $264-297$ & $271-300$ & $269-297$ \\
\hline & $\mathbf{W S}$ & $305-314$ & $307-316$ & $308-317$ & $308-317$ & $307-316$ \\
\hline & $\mathbf{S}$ & $274-313$ & $272-314$ & $271-314$ & $274-314$ & $271-314$ \\
\hline \multirow{4}{*}{$\begin{array}{c}\text { Mean } D_{p} \\
\left(^{\circ}\right)\end{array}$} & $\mathbf{N}$ & $269-285$ & $265-283$ & 259-279 & $263-281$ & $264-282$ \\
\hline & $\mathbf{W N}$ & $252-258$ & $245-252$ & $239-247$ & $245-253$ & $247-256$ \\
\hline & WS & $267-275$ & $262-272$ & $261-270$ & $263-271$ & $270-277$ \\
\hline & $\mathbf{S}$ & $277-311$ & $274-311$ & $274-312$ & $276-312$ & $274-312$ \\
\hline
\end{tabular}

Significant wave height values (mean $\mathrm{H}_{\mathrm{s}}, \mathrm{H}_{\mathrm{s}, 0.95}$, and maximum $\mathrm{H}_{\mathrm{s}}$ ) decrease, in general, from the northern to southern station groups in the sequence $\mathrm{WN}>\mathrm{N}>\mathrm{WS}>\mathrm{S}$, where values found for $\mathrm{S}$ are considerably lower than those of the remaining station groups. Comparing the $\mathrm{HP}$ results for mean $\mathrm{H}_{\mathrm{s}}, \mathrm{H}_{\mathrm{s}, 0.95}$, and maximum $\mathrm{H}_{\mathrm{s}}$ among the station groups, it was found that $\mathrm{H}_{\mathrm{s}, 0.95}$ values are twice the mean $\mathrm{H}_{\mathrm{s}}$ values, and the maximum $\mathrm{H}_{\mathrm{s}}$ is thrice the $\mathrm{H}_{\mathrm{s}, 0.95}$ values (ranges from 1.25-2.97 $\mathrm{m}$ for mean $\mathrm{H}_{\mathrm{s}} ; 2.82-5.91 \mathrm{~m}$ for $\mathrm{H}_{\mathrm{s}, 0.95}$; and 8.54-15.59 $\mathrm{m}$ for maximum $\mathrm{H}_{\mathrm{s}}$ ).

For each station group, when historical values are compared with the projected results of the RCPs scenarios for mean $\mathrm{H}_{\mathrm{s}}$ and $\mathrm{H}_{\mathrm{s}, 0.95}$, tendencies show that HP results are higher than those calculated in any of the RCPs scenarios. For example, differences in percentage between RCP8.5_mid scenario and HP for the most energetic station group (WN) show $\mathrm{H}_{\mathrm{s}}$ minimum and maximum values of: $-2.82 \%$ and $-4.04 \%$ for mean $\mathrm{H}_{\mathrm{s}}$; $2.55 \%$ and $-3.21 \%$ for $\mathrm{H}_{\mathrm{s}, 0.95}$; and $-22.72 \%$ and $-3.31 \%$ for $\max \mathrm{H}_{\mathrm{s} .}$ Regarding the differences between RCP8.5_end scenario and HP, the corresponding percentages are: $6.69 \%$ and $-8.08 \%$ for mean $\mathrm{H}_{\mathrm{s}} ;-3.83 \%$ and $-4.91 \%$ for $\mathrm{H}_{\mathrm{s}, 0.95}$; and $+7.55 \%$ and $+34.59 \%$ for $\max \mathrm{H}_{\mathrm{s}}$. Similar results for the Iberian coast can also be found in the assessment of CMIP5 wave projections conducted by Morim et al. (2019). These results are very important as they contradict results obtained by other authors when the effects of climate change on $\mathrm{H}_{\mathrm{s}}$ are simulated. Wang and Swail (2001) showed significant 
linear increasing trends on wave height in both the North Atlantic and North Pacific, when the global model hindcast results were analysed for the time period of 1958-1997. In a more recent study, Wang et al. (2016) presented results showing $\mathrm{H}_{\mathrm{s}}$ increases in the tropics (especially in the eastern tropical Pacific) and in southern hemisphere highlatitudes, which are based on the CMIP5 historical (2005), RCP4.5 (2050) and RCP8.5 (2099) forcing scenario simulations. Moreover, tendencies show that projected values obtained for RCP4.5 and RCP8.5 scenarios have slight differences apparently without major influence on these wave statistical results.

Maximum $\mathrm{H}_{\mathrm{s}}$ values show contradictory tendencies when HP data are compared to projected data. The maximum values obtained for RCP4.5_mid and RCP8.5_end scenarios are higher (10-35\%) than those of the HP data for the northern station groups $\mathrm{N}$ and $\mathrm{WN}$ (ranging from $16.79 \mathrm{~m}$ to $20.74 \mathrm{~m}$, respectively) and lower for the southern station groups WS (13.37 $\mathrm{m}$ to $13.95 \mathrm{~m})$ and S (10.51 m to $12.32 \mathrm{~m})$. For RCP4.5_end and RCP8.5_mid scenarios, the results obtained follow the same tendency as verified with mean $\mathrm{H}_{\mathrm{s}}$, and $\mathrm{H}_{\mathrm{s}, 0.95}$, with lower values than those of the HP data. This can be justified by the fact that the use of model data often originates undervaluation of the $\mathrm{H}_{\mathrm{s}}$ in projected scenarios.

Mean $\mathrm{T}_{\mathrm{p}}$ appears to maintain constant values around $10.50 \mathrm{~s}$ in all station groups, independently the scenario considered.

Wave direction defined by $D_{m}$ and $D_{p}$ values show slight differences both in station group location and in wave climate regime scenarios. However, it can be noted that for $\mathrm{D}_{\mathrm{m}}$ the values for $\mathrm{N}$ and $\mathrm{WN}$ station groups have analogous behaviour with maximum values around $300^{\circ}$, and in WS and $\mathrm{S}$ station groups maximum values around $315^{\circ} . \mathrm{D}_{\mathrm{p}}$ maximum values around $280^{\circ}, 250^{\circ}, 275^{\circ}$, and $312^{\circ}$ can be found in station groups $\mathrm{N}$, WN, WS, S, respectively.

\subsection{Descriptive statistics: storm sub-dataset}

Storm sub-dataset for the five wave climate regime scenarios were used to calculate mean peak storm $\mathrm{H}_{\mathrm{s}}$, mean storm $\mathrm{T}_{\mathrm{p}}$, total number of storms, mean storms per year and storm durations. Figure 5 presents the results obtained for these five wave climate regime scenarios.

Table 6 shows minimum and maximum values obtained for storm wave data in each station group for the five wave climate regime scenarios. Mean peak storm $\mathrm{H}_{\mathrm{s}}$ and mean storm $\mathrm{T}_{\mathrm{p}}$, as well as total number of storms, mean storms per year, mean storm duration, and maximum storm duration are presented.

For mean peak storm $\mathrm{H}_{\mathrm{s}}$, differences in percentage between RCP8.5_mid scenario and $\mathrm{HP}$ for the most energetic station group (WN) show $\mathrm{H}_{\mathrm{s}}$ minimum and maximum values of $+1.01 \%$ and $-1.21 \%$. Regarding the differences between RCP8.5_end scenario and $\mathrm{HP}$, the corresponding percentages are $+4.49 \%$ and $+3.23 \%$. 
Table 6. Descriptive statistics results for the local wave regime using storm sub-dataset (1).

\begin{tabular}{|c|c|c|c|c|c|c|}
\hline \multirow{2}{*}{$\begin{array}{l}\text { Wave } \\
\text { data }\end{array}$} & \multirow{2}{*}{$\begin{array}{l}\text { Station } \\
\text { Group }\end{array}$} & \multicolumn{5}{|c|}{ Wave climate regime scenario } \\
\hline & & $\mathbf{H P}$ & RCP4.5_mid & RCP4.5_end & RCP8.5_mid & RCP8.5_end \\
\hline \multirow{4}{*}{$\begin{array}{c}\text { Mean } \\
\text { peak } \\
\text { storm Hs } \\
\quad(\mathbf{m})\end{array}$} & $\mathbf{N}$ & $6.59-7.28$ & $6.60-7.26$ & $6.53-7.24$ & $6.57-7.14$ & $6.71-7.50$ \\
\hline & WN & $6.90-7.42$ & $6.96-7.49$ & $6.98-7.43$ & $6.97-7.33$ & $7.21-7.66$ \\
\hline & WS & $6.09-6.73$ & $6.13-6.77$ & $6.09-6.85$ & $6.11-6.77$ & $6.29-6.88$ \\
\hline & $\mathbf{S}$ & $3.77-5.98$ & $3.78-5.97$ & $3.74-5.98$ & $3.71-5.99$ & $3.91-6.17$ \\
\hline \multirow{4}{*}{$\begin{array}{c}\text { Mean } \\
\text { storm } \mathbf{T}_{p} \\
\quad(\mathbf{s})\end{array}$} & $\mathbf{N}$ & $14.02-14.28$ & $13.83-14.15$ & $13.54-13.95$ & $13.66-14.15$ & $13.83-14.14$ \\
\hline & $\mathbf{W N}$ & $13.94-14.03$ & $13.81-14.11$ & $13.44-13.75$ & $13.54-13.66$ & $13.72-13.83$ \\
\hline & WS & $13.93-14.00$ & $13.75-14.03$ & $13.66-13.83$ & $13.57-13.77$ & $13.88-14.05$ \\
\hline & $\mathbf{S}$ & $12.52-14.04$ & $12.56-13.80$ & $12.29-13.89$ & $12.38-13.80$ & $13.04-14.06$ \\
\hline \multirow{4}{*}{$\begin{array}{c}\text { Total } \\
\text { number } \\
\text { of storms }\end{array}$} & $\mathbf{N}$ & $819-827$ & $314-324$ & $291-296$ & $301-327$ & $281-282$ \\
\hline & WN & $798-820$ & $281-301$ & $253-289$ & $311-327$ & $272-282$ \\
\hline & $\mathbf{W S}$ & $754-805$ & $278-288$ & $228-248$ & $283-303$ & $244-269$ \\
\hline & $\mathbf{S}$ & $648-747$ & $256-284$ & $206-226$ & $258-283$ & $222-241$ \\
\hline \multirow{4}{*}{$\begin{array}{c}\text { Mean } \\
\text { storms } \\
\text { per year }\end{array}$} & $\mathbf{N}$ & $18-18$ & $16-16$ & $15-15$ & $15-16$ & $14-14$ \\
\hline & WN & $17-18$ & $14-15$ & $13-14$ & $16-16$ & $14-14$ \\
\hline & WS & $16-18$ & $14-14$ & $11-12$ & $14-15$ & $12-13$ \\
\hline & $\mathbf{S}$ & $14-16$ & $13-14$ & $10-11$ & $13-14$ & $11-12$ \\
\hline \multirow{4}{*}{$\begin{array}{c}\text { Mean } \\
\text { storm } \\
\text { duration } \\
\text { (h) }\end{array}$} & $\mathbf{N}$ & $21-22$ & $21-22$ & 19-19 & $21-22$ & $21-23$ \\
\hline & WN & $22-22$ & $22-24$ & $19-22$ & $21-22$ & $22-23$ \\
\hline & WS & $22-24$ & $23-25$ & $21-23$ & $22-24$ & $24-26$ \\
\hline & $\mathbf{S}$ & $24-28$ & $23-28$ & $22-27$ & $23-26$ & $26-31$ \\
\hline \multirow{4}{*}{$\begin{array}{c}\text { Max. } \\
\text { storm } \\
\text { duration } \\
\text { (h) }\end{array}$} & $\mathbf{N}$ & $168-174$ & $132-135$ & $93-123$ & $117-171$ & $117-126$ \\
\hline & $\mathbf{W N}$ & $177-198$ & $132-135$ & $123-135$ & $108-117$ & $123-141$ \\
\hline & WS & $132-138$ & $108-135$ & $135-162$ & $87-99$ & $138-228$ \\
\hline & $\mathbf{S}$ & $147-243$ & $135-201$ & $162-204$ & $102-156$ & $144-228$ \\
\hline
\end{tabular}



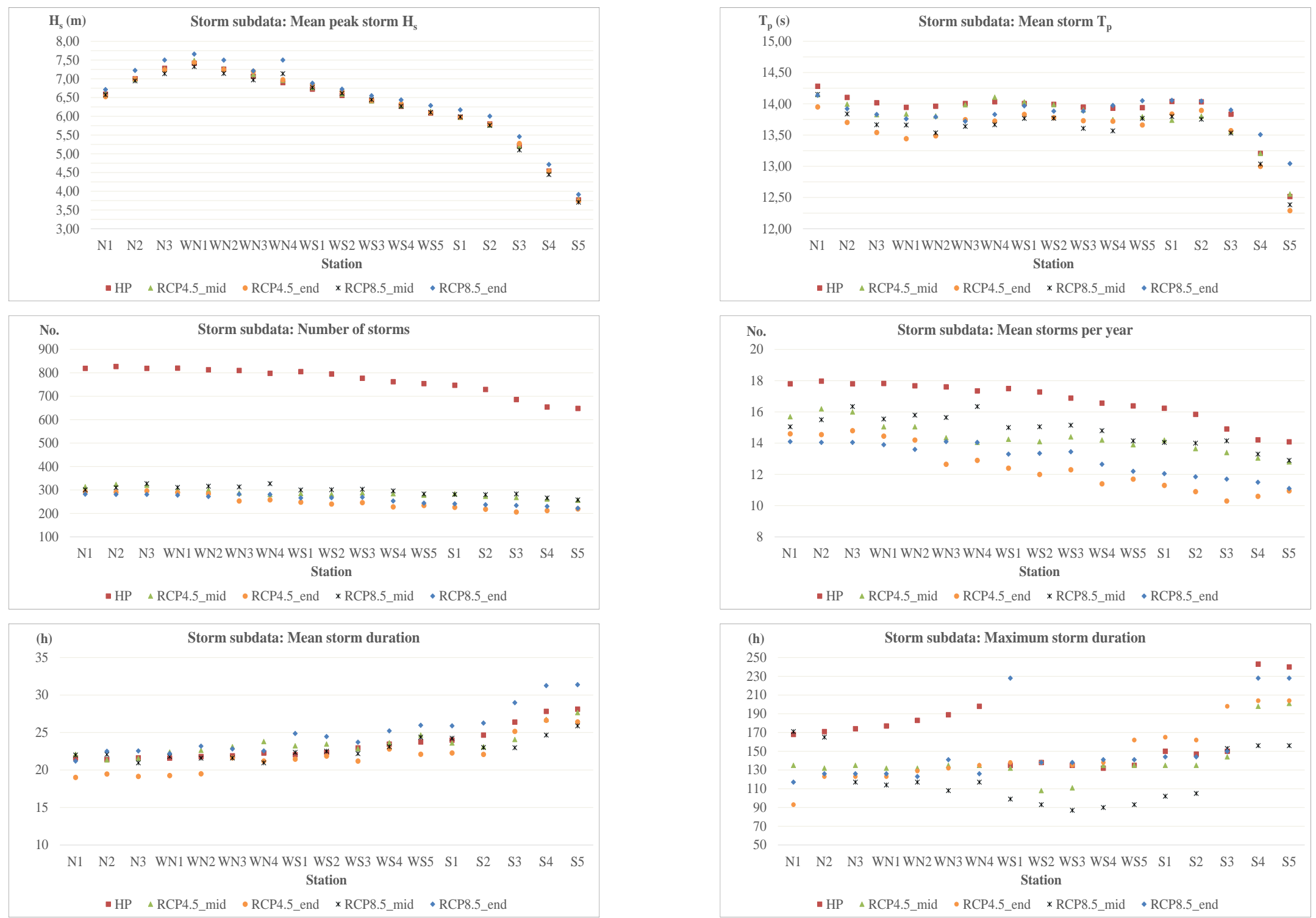

Figure 5. Mean peak storm $\mathrm{H}_{s}$, mean storm $\mathrm{T}_{\mathrm{p}}$, total number of storms, mean storms per year and storm durations results under five wave climate regime scenarios. 
Mean peak storm $\mathrm{H}_{\mathrm{s}}$ decrease, in general, from the northern to southern groups of stations in the sequence $\mathrm{WN}>\mathrm{N}>\mathrm{WS}>\mathrm{S}$, where values found for $\mathrm{S}$ are considerably lower (approximately, one-half in minimum values) than those of the remaining station groups. The results obtained for RCPs scenarios are similar to the historical ones, notwithstanding there is a slight increase in these values for the climate scenario RCP8.5_end.

The results obtained for mean storm $\mathrm{T}_{\mathrm{p}}$ show similar values in the range [13-14 s], independently the station groups and the scenario considered.

Total number of storms values decrease in the sequence of $\mathrm{N}>\mathrm{WN}>\mathrm{WS}>\mathrm{S}$, as well as from the historical (maximum values ranging from 747-827 in 46 years) to the RCPs (maximum values ranging from 226-327 in 46 years) scenarios. Mean storms per year have the same behaviour as total number of storms, with values ranging from 10 to 18 events per year.

Results for mean storm duration values show a slight increase in the sequence of $\mathrm{N}>\mathrm{WN}>\mathrm{WS}>\mathrm{S}$ (with maxima in the range of 22-28 h), while small variations for the different scenarios are verified. Maximum storm duration values have a decreasing behaviour in the sequence of $\mathrm{N}>\mathrm{WN}>\mathrm{WS}>\mathrm{S}$ for HP data, and an increase behaviour for RCP4.5_end and RCP8.5_end in the same sequence. Maximum storm duration projected values for RCPs in S are higher than in N, WN, and WS with maximum values ranging from $156 \mathrm{~h}$ to $228 \mathrm{~h}$.

Figure 6 presents mean $D_{m}$ and mean $D_{p}$ results obtained from the storm sub-dataset for the five wave climate regime scenarios. Frequency analysis of mean $D_{m}$ and mean $D_{p}$, associated to peak storm wave height for the fourth quadrant $\left(\mathrm{Q} 4: 270^{\circ}-360^{\circ}\right)$ are also presented in Figure 6.
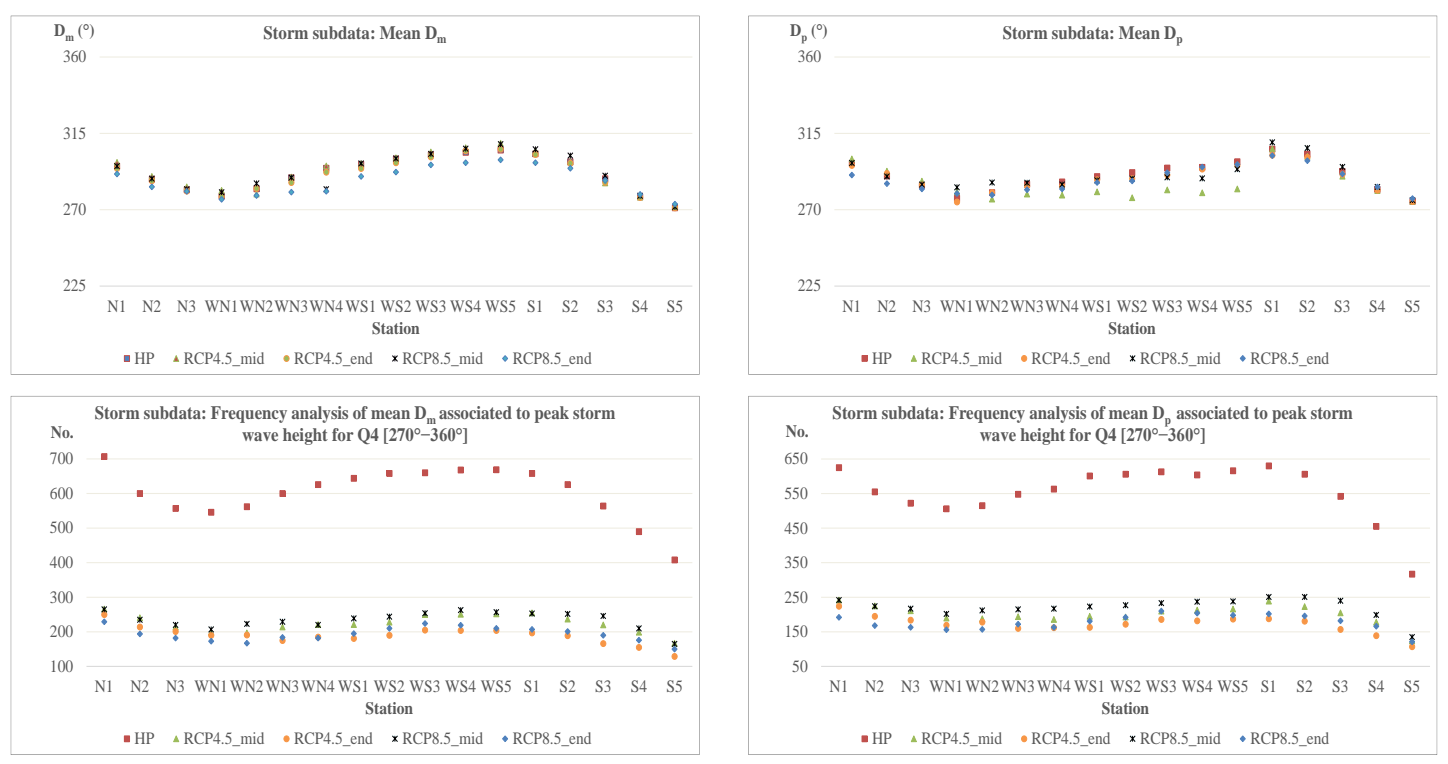

Figure 6. Results for mean $D_{m}$, mean $D_{p}$, and frequency analysis of mean $D_{m}$ and mean $D_{p}$ for $Q 4$.

Table 7 shows minimum and maximum values obtained for mean $D_{m}$ and $D_{p}$, in each station group for the five wave climate regime scenarios. In addition, for these two wave data, the range of percentages of their occurrence in the $\mathrm{Q} 4\left[270^{\circ}-360^{\circ}\right]$ related to the other three quadrants are also presented. 
Table 7. Descriptive statistics results for the local wave regime using storm sub-dataset (2).

\begin{tabular}{|c|c|c|c|c|c|c|}
\hline \multirow{2}{*}{$\begin{array}{l}\text { Wave } \\
\text { data }\end{array}$} & \multirow{2}{*}{$\begin{array}{l}\text { Station } \\
\text { Group }\end{array}$} & \multicolumn{5}{|c|}{ Wave climate regime scenario } \\
\hline & & HP & RCP4.5_mid & RCP4.5_end & RCP8.5_mid & RCP8.5_end \\
\hline \multirow{4}{*}{$\begin{array}{c}\text { Mean } D_{m} \\
\left(^{\circ}\right)\end{array}$} & $\mathbf{N}$ & $282-296$ & $283-298$ & $281-294$ & $282-296$ & $281-291$ \\
\hline & $\mathbf{W N}$ & $278-294$ & 279-296 & $278-292$ & $280-289$ & $276-281$ \\
\hline & WS & $297-305$ & 297-309 & 294-306 & 297-309 & 290-299 \\
\hline & $\mathbf{S}$ & $271-303$ & $272-305$ & $271-303$ & $272-306$ & $273-298$ \\
\hline \multirow{4}{*}{$\begin{array}{c}\text { Mean } D_{p} \\
\left(^{\circ}\right)\end{array}$} & $\mathbf{N}$ & $284-297$ & $287-300$ & $285-296$ & $285-298$ & $282-290$ \\
\hline & $\mathbf{W N}$ & $277-286$ & $276-281$ & $275-284$ & $283-286$ & $279-282$ \\
\hline & WS & $290-298$ & $277-282$ & $288-296$ & $287-294$ & $286-297$ \\
\hline & $\mathbf{S}$ & $275-306$ & $275-306$ & $275-302$ & $276-310$ & $277-302$ \\
\hline \multirow{4}{*}{$\begin{array}{l}\text { Q4 Freq. } \\
\text { Mean Dm } \\
\quad(\%)\end{array}$} & $\mathbf{N}$ & $68-86$ & $67-85$ & $68-86$ & $67-88$ & $65-81$ \\
\hline & $\mathbf{W N}$ & $67-78$ & $65-79$ & $66-72$ & $67-73$ & $61-65$ \\
\hline & WS & $80-89$ & $78-91$ & $73-89$ & $80-91$ & $73-87$ \\
\hline & $\mathbf{S}$ & $63-88$ & $65-90$ & 59-87 & $64-90$ & $68-86$ \\
\hline \multirow{4}{*}{$\begin{array}{l}\text { Q4 Freq. } \\
\text { Mean } D_{p} \\
\quad(\%)\end{array}$} & $\mathbf{N}$ & 77-92 & $78-91$ & $73-89$ & $78-95$ & $71-86$ \\
\hline & WN & $75-85$ & $75-86$ & $70-80$ & $76-83$ & $68-75$ \\
\hline & WS & $86-95$ & $86-94$ & $86-93$ & $88-95$ & $83-94$ \\
\hline & $\mathbf{S}$ & $81-94$ & $82-94$ & $79-93$ & $82-96$ & $85-95$ \\
\hline
\end{tabular}

The results obtained for either mean $D_{m}$ or mean $D_{p}$ show similar values in the range $\left[271^{\circ}-310^{\circ}\right]$, independently the station groups and the scenario considered. For HP data, the occurrence of the wave directions falling in the $\mathrm{Q} 4$ have a frequency ranging from $63 \%$ to $89 \%$ for mean $\mathrm{D}_{\mathrm{m}}$ and from $75 \%$ to $94 \%$ for mean $\mathrm{D}_{\mathrm{p}}$. It is also relevant to mention that the second most frequent wave direction falls in the third quadrant $(\mathrm{Q} 3$ : $\left.180^{\circ}-270^{\circ}\right)$.

\subsection{Extreme values analysis}

\subsubsection{Historical data}

Storm data was used as the basis for extreme wave climate regime analysis. Since the probability distribution methods (Gumbel, Fréchet and Weibull) applied in this study are built on specific assumptions, a comparison of the estimates obtained by each of these methods has been performed. The three methods used the HP dataset for estimating $\mathrm{H}_{\mathrm{s}}$ and $\mathrm{T}_{\mathrm{p}}$ of three return periods: 10-, 50-, 100-year. As a representative example, Figure 7 shows the results obtained for determining extreme values for $\mathrm{H}_{\mathrm{s}}$ and $\mathrm{T}_{\mathrm{p}}$ in one of the stations, applying the percent point function plotting technique. 

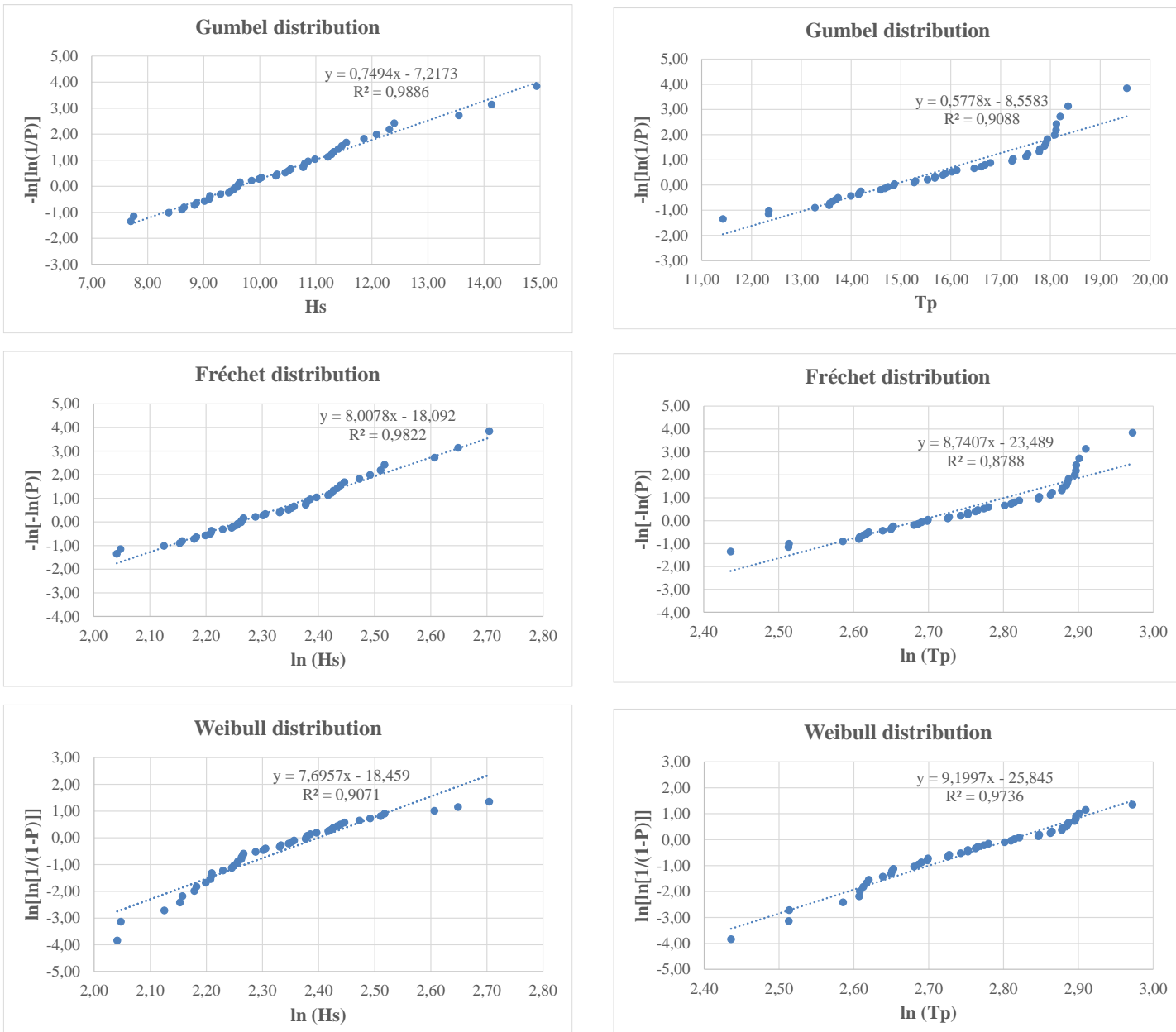

Figure 7. Parameter estimation of extreme value distribution using the least squares method for $H_{s}$ and $T_{p}$ in station WN3.

Table 8 summaries the estimates for wave data $\left(\mathrm{H}_{\mathrm{s}}\right.$ and $\left.\mathrm{T}_{\mathrm{p}}\right)$ applying the three probability distribution methods in all stations for the considered return periods. The obtained coefficient of determination $\left(\mathrm{R}^{2}\right)$ value, which served as selection factor of the most appropriate method to apply in the RCP4.5 and RCP8.5 scenarios, is presented in Table 9. From the calculated results, it can be noted that Fréchet distribution overestimates wave heights for longer return periods. However, this distribution provided higher $\mathrm{R}^{2}$ values in estimating $\mathrm{H}_{\mathrm{s}}$ results, whereas Weibull distribution has demonstrated to give the best fit (higher $\mathrm{R}^{2}$ values) for the $\mathrm{T}_{\mathrm{p}}$. 
Table 8. Extreme wave climate analysis for the historical scenario in all stations. Comparison of $\mathrm{H}_{\mathrm{s}}$ and $\mathrm{T}_{\mathrm{p}}$ values for 10-, 50-, and 100-year return periods obtained with the application of Gumbel, Fréchet and Weibull probability distributions.

\begin{tabular}{|c|c|c|c|c|c|c|c|}
\hline \multirow{2}{*}{ Station } & \multirow{2}{*}{$\mathbf{T}_{\mathbf{r}}($ years $)$} & \multicolumn{3}{|c|}{$\mathrm{H}_{\mathrm{s}}(\mathrm{m})$} & \multicolumn{3}{|c|}{$T_{p}(s)$} \\
\hline & & Gumbel & Fréchet & Weibull & Gumbel & Fréchet & Weibull \\
\hline \multirow{3}{*}{ N1 } & 10 & 12.00 & 12.19 & 11.64 & 18.56 & 18.72 & 18.13 \\
\hline & 50 & 14.07 & 15.12 & 12.46 & 21.04 & 21.91 & 19.05 \\
\hline & 100 & 14.95 & 16.57 & 12.72 & 22.08 & 23.41 & 19.35 \\
\hline \multirow{3}{*}{$\mathbf{N} 2$} & 10 & 12.72 & 12.85 & 12.35 & 18.24 & 18.40 & 17.82 \\
\hline & 50 & 14.90 & 15.83 & 13.21 & 20.64 & 21.49 & 18.72 \\
\hline & 100 & 15.82 & 17.28 & 13.49 & 21.66 & 22.94 & 19,00 \\
\hline \multirow{3}{*}{ N3 } & 10 & 13,01 & 13,12 & 12,63 & 18,17 & 18,29 & 17,73 \\
\hline & 50 & 15,23 & 16,12 & 13,51 & 20,67 & 21,51 & 18,68 \\
\hline & 100 & 16,16 & 17,58 & 13,79 & 21,73 & 23,03 & 18,99 \\
\hline \multirow{3}{*}{ WN1 } & 10 & 13.23 & 13.38 & 12.85 & 17.96 & 18.12 & 17.53 \\
\hline & 50 & 15.52 & 16.53 & 13.76 & 20.44 & 21.34 & 18.47 \\
\hline & 100 & 16.49 & 18.08 & 14.05 & 21.49 & 22.86 & 18.77 \\
\hline \multirow{3}{*}{ WN2 } & 10 & 12.93 & 13.04 & 12.56 & 18.18 & 18.41 & 17.72 \\
\hline & 50 & 15.18 & 16.08 & 13.45 & 20.80 & 21.91 & 18.71 \\
\hline & 100 & 16.13 & 17.57 & 13.74 & 21.91 & 23.58 & 19.03 \\
\hline \multirow{3}{*}{ WN3 } & 10 & 12.63 & 12.68 & 12.27 & 18.71 & 19.01 & 18.17 \\
\hline & 50 & 14.84 & 15.59 & 13.14 & 21.56 & 22.96 & 19.25 \\
\hline & 100 & 15.77 & 17.01 & 13.42 & 22.77 & 24.87 & 19.60 \\
\hline \multirow{3}{*}{ WN4 } & 10 & 12.34 & 12.36 & 11.98 & 18.69 & 19.02 & 18.18 \\
\hline & 50 & 14.56 & 15.28 & 12.88 & 21.44 & 22.83 & 19.20 \\
\hline & 100 & 15.50 & 16.71 & 13.16 & 22.60 & 24.66 & 19.53 \\
\hline \multirow{3}{*}{ WS1 } & 10 & 12.14 & 12.10 & 11.78 & 18.62 & 18.93 & 18.12 \\
\hline & 50 & 14.36 & 14.94 & 12.68 & 21.36 & 22.71 & 19.15 \\
\hline & 100 & 15.31 & 16.34 & 12.97 & 22.52 & 24.53 & 19.48 \\
\hline \multirow{3}{*}{ WS2 } & 10 & 11.86 & 11.73 & 11.47 & 18.25 & 18.44 & 17.80 \\
\hline & 50 & 14.08 & 14.45 & 12.36 & 20.78 & 21.76 & 18.76 \\
\hline & 100 & 15.02 & 15.79 & 12.64 & 21.86 & 23.34 & 19.06 \\
\hline \multirow{3}{*}{ WS3 } & 10 & 11.62 & 11.43 & 11.21 & 18.04 & 18.22 & 17.60 \\
\hline & 50 & 13.86 & 14.10 & 12.09 & 20.46 & 21.38 & 18.51 \\
\hline & 100 & 14.81 & 15.41 & 12.38 & 21.48 & 22.87 & 18.80 \\
\hline \multirow{3}{*}{ WS4 } & 10 & 11.30 & 11.10 & 10.92 & 18.40 & 18.66 & 17.92 \\
\hline & 50 & 13.46 & 13.66 & 11.78 & 21.26 & 22.59 & 19.03 \\
\hline & 100 & 14.38 & 14.91 & 12.06 & 22.47 & 24.50 & 19.39 \\
\hline \multirow{3}{*}{ WS5 } & 10 & 10.88 & 10.79 & 10.55 & 18.25 & 18.59 & 17.75 \\
\hline & 50 & 12.88 & 13.27 & 11.35 & 21.20 & 22.79 & 18.90 \\
\hline & 100 & 13.73 & 14.48 & 11.61 & 22.44 & 24.83 & 19.27 \\
\hline \multirow{3}{*}{ S1 } & 10 & 10.47 & 10.40 & 10.20 & 18.59 & 18.98 & 18.06 \\
\hline & 50 & 12.28 & 12.64 & 10.93 & 21.61 & 23.33 & 19.24 \\
\hline & 100 & 13.05 & 13.73 & 11.17 & 22.89 & 25.46 & 19.61 \\
\hline \multirow{3}{*}{ S2 } & 10 & 10.11 & 10.06 & 9.85 & 18.73 & 19.10 & 18.20 \\
\hline & 50 & 11.86 & 12.24 & 10.56 & 21.69 & 23.32 & 19.33 \\
\hline & 100 & 12.60 & 13.30 & 10.78 & 22.94 & 25.38 & 19.70 \\
\hline \multirow{3}{*}{ S3 } & 10 & 9.43 & 9.42 & 9.15 & 18.28 & 18.69 & 17.73 \\
\hline & 50 & 11.14 & 11.63 & 9.84 & 21.48 & 23.39 & 18.98 \\
\hline & 100 & 11.86 & 12.72 & 10.06 & 22.83 & 25.72 & 19.39 \\
\hline & 10 & 8.69 & 8.70 & 8.40 & 17.54 & 17.92 & 16.99 \\
\hline S4 & 50 & 10.45 & 11.08 & 9.12 & 20.67 & 22.51 & 18.22 \\
\hline & 100 & 11.19 & 12.28 & 9.35 & 21.99 & 24.79 & 18.61 \\
\hline & 10 & 7.50 & 7.56 & 7.22 & 17.09 & 17.41 & 16.56 \\
\hline S5 & 50 & 9.13 & 9.93 & 7.91 & 20.41 & 22.30 & 17.92 \\
\hline & 100 & 9.82 & 11.14 & 8.13 & 21.81 & 24.75 & 18.36 \\
\hline
\end{tabular}


Table 9. Extreme wave climate analysis for the historical scenario in all stations. Comparison of $\mathrm{R}^{2}$ values obtained with the application of Gumbel, Fréchet and Weibull probability distributions.

\begin{tabular}{|c|c|c|c|c|c|c|}
\hline \multirow{2}{*}{ Station } & \multicolumn{3}{|c|}{$\mathbf{H}_{\mathrm{s}}(\mathrm{m})$} & \multicolumn{3}{|c|}{$\mathbf{T}_{\mathbf{p}}(\mathbf{s})$} \\
\hline & Gumbel & Fréchet & Weibull & Gumbel & Fréchet & Weibull \\
\hline N1 & 0.954 & 0.922 & 0.961 & 0.958 & 0.936 & 0.957 \\
\hline N2 & 0.960 & 0.941 & 0.931 & 0.959 & 0.934 & 0.960 \\
\hline N3 & 0.970 & 0.953 & 0.929 & 0.968 & 0.951 & 0.942 \\
\hline WN1 & 0.979 & 0.955 & 0.943 & 0.963 & 0.939 & 0.954 \\
\hline WN2 & 0.977 & 0.961 & 0.921 & 0.949 & 0.918 & 0.968 \\
\hline WN3 & 0.989 & 0.982 & 0.907 & 0.909 & 0.879 & 0.974 \\
\hline WN4 & 0.993 & 0.993 & 0.886 & 0.908 & 0.870 & 0.990 \\
\hline WS1 & 0.973 & 0.986 & 0.842 & 0.928 & 0.889 & 0.989 \\
\hline WS2 & 0.940 & 0.973 & 0.796 & 0.961 & 0.935 & 0.969 \\
\hline WS3 & 0.906 & 0.955 & 0.758 & 0.961 & 0.932 & 0.975 \\
\hline WS4 & 0.901 & 0.952 & 0.733 & 0.937 & 0.908 & 0.943 \\
\hline WS5 & 0.958 & 0.984 & 0.808 & 0.943 & 0.900 & 0.976 \\
\hline S1 & 0.963 & 0.983 & 0.797 & 0.921 & 0.878 & 0.976 \\
\hline $\mathbf{S 2}$ & 0.961 & 0.977 & 0.804 & 0.915 & 0.873 & 0.980 \\
\hline $\mathbf{S 3}$ & 0.969 & 0.976 & 0.856 & 0.926 & 0.887 & 0.979 \\
\hline S4 & 0.962 & 0.964 & 0.859 & 0.920 & 0.888 & 0.974 \\
\hline S5 & 0.973 & 0.963 & 0.905 & 0.936 & 0.913 & 0.928 \\
\hline
\end{tabular}

\subsubsection{Projected data}

Extreme wave climate regime projections for RCP4.5 and RCP8.5 scenarios were performed using the Fréchet and the Weibull methods in estimating $\mathrm{H}_{\mathrm{s}}$ and $\mathrm{T}_{\mathrm{p}}$, respectively. Wave data values were calculated for 10-, 50-, 100-year return periods.

Table 10 summarizes the estimation of wave data under the RCPs scenarios for 10-, 50-, and 100-year return periods at all stations. 
Table 10. Extreme wave climate values estimated by using the Fréchet and Weibull probability distributions under the RCP4.5_mid, RCP4.5_end, RCP8.5_mid and RCP8.5_end scenarios for 10-, 50-, and 100-year return periods at all stations.

\begin{tabular}{|c|c|c|c|c|c|c|c|c|c|}
\hline \multirow{2}{*}{ Station } & \multirow{2}{*}{$\mathbf{T}_{\mathbf{r}}($ years $)$} & \multicolumn{2}{|c|}{ RCP4.5_mid } & \multicolumn{2}{|c|}{ RCP4.5_end } & \multicolumn{2}{|c|}{ RCP8.5_mid } & \multicolumn{2}{|c|}{ RCP8.5_end } \\
\hline & & $\mathbf{H}_{\mathbf{S}}(\mathbf{m})$ & $\mathbf{T}_{\mathbf{p}}(\mathbf{s})$ & $\mathbf{H}_{\mathrm{s}}(\mathrm{m})$ & $\mathbf{T}_{\mathbf{p}}(\mathbf{s})$ & $\mathbf{H}_{\mathrm{s}}(\mathrm{m})$ & $\mathbf{T}_{\mathbf{p}}(\mathbf{s})$ & $\mathbf{H}_{\mathrm{s}}(\mathrm{m})$ & $T_{p}(s)$ \\
\hline \multirow{3}{*}{ N1 } & 10 & 13.36 & 17.91 & 11.80 & 17.04 & 12.12 & 18.01 & 13.23 & 17.62 \\
\hline & 50 & 18.28 & 18.97 & 14.44 & 17.87 & 15.71 & 18.91 & 17.63 & 18.61 \\
\hline & 100 & 20.87 & 19.31 & 15.73 & 18.13 & 17.53 & 19.20 & 19.90 & 18.93 \\
\hline \multirow{3}{*}{$\mathbf{N} 2$} & 10 & 14.17 & 17.79 & 13.10 & 16.90 & 12.87 & 18.02 & 15.37 & 17.29 \\
\hline & 50 & 18.96 & 18.97 & 16.62 & 17.81 & 16.76 & 19.18 & 21.70 & 18.07 \\
\hline & 100 & 21.44 & 19.35 & 18.38 & 18.11 & 18.74 & 19.56 & 25.11 & 18.32 \\
\hline \multirow{3}{*}{ N3 } & 10 & 14.62 & 18.01 & 13.66 & 17.38 & 13.18 & 17.62 & 15.96 & 17.23 \\
\hline & 50 & 19.42 & 19.20 & 17.47 & 18.50 & 17.05 & 18.77 & 22.64 & 17.95 \\
\hline & 100 & 21.90 & 19.58 & 19.39 & 18.86 & 19.01 & 19.14 & 26.25 & 18.18 \\
\hline \multirow{3}{*}{ WN1 } & 10 & 14.67 & 18.20 & 13.93 & 16.65 & 13.32 & 17.77 & 16.32 & 17.19 \\
\hline & 50 & 19.47 & 19.36 & 17.74 & 17.41 & 17.26 & 18.94 & 23.14 & 17.87 \\
\hline & 100 & 21.94 & 19.73 & 19.66 & 17.66 & 19.26 & 19.32 & 26.81 & 18.09 \\
\hline \multirow{3}{*}{ WN2 } & 10 & 13.87 & 17.90 & 14.15 & 16.99 & 12.94 & 17.49 & 15.80 & 17.63 \\
\hline & 50 & 18.05 & 19.16 & 18.71 & 17.77 & 16.39 & 18.62 & 22.12 & 18.49 \\
\hline & 100 & 20.17 & 19.56 & 21.05 & 18.02 & 18.11 & 18.98 & 25.50 & 18.76 \\
\hline \multirow{3}{*}{ WN3 } & 10 & 13.00 & 18.06 & 13.98 & 17.18 & 12.27 & 17.39 & 15.10 & 17.33 \\
\hline & 50 & 16.55 & 19.39 & 18.80 & 18.00 & 15.12 & 18.45 & 20.76 & 18.13 \\
\hline & 100 & 18.33 & 19.82 & 21.31 & 18.26 & 16.51 & 18.79 & 23.75 & 18.39 \\
\hline \multirow{3}{*}{ WN4 } & 10 & 12.42 & 18.01 & 13.49 & 17.11 & 13.18 & 17.62 & 15.96 & 17.23 \\
\hline & 50 & 15.76 & 19.22 & 18.04 & 17.90 & 17.05 & 18.77 & 22.64 & 17.95 \\
\hline & 100 & 17.44 & 19.61 & 20.40 & 18.15 & 19.01 & 19.14 & 26.25 & 18.18 \\
\hline \multirow{3}{*}{ WS1 } & 10 & 12.19 & 18.76 & 13.12 & 17.16 & 10.80 & 17.13 & 13.68 & 17.20 \\
\hline & 50 & 15.69 & 20.30 & 17.69 & 18.01 & 12.34 & 18.15 & 18.19 & 17.89 \\
\hline & 100 & 17.46 & 20.80 & 20.07 & 18.28 & 13.06 & 18.48 & 20.53 & 18.11 \\
\hline \multirow{3}{*}{ WS2 } & 10 & 11.70 & 18.55 & 12.62 & 17.02 & 10.58 & 16.74 & 13.22 & 17.20 \\
\hline & 50 & 14.89 & 20.02 & 17.11 & 17.79 & 11.98 & 17.60 & 17.69 & 17.93 \\
\hline & 100 & 16.49 & 20.50 & 19.45 & 18.03 & 12.63 & 17.87 & 20.01 & 18.16 \\
\hline \multirow{3}{*}{ WS3 } & 10 & 11.43 & 18.61 & 11.87 & 17.26 & 10.58 & 16.70 & 12.63 & 16.97 \\
\hline & 50 & 14.60 & 20.21 & 15.80 & 18.20 & 12.13 & 17.56 & 16.64 & 17.74 \\
\hline & 100 & 16.18 & 20.73 & 17.83 & 18.49 & 12.85 & 17.83 & 18.70 & 17.98 \\
\hline \multirow{3}{*}{ WS4 } & 10 & 11.20 & 17.36 & 11.31 & 17.24 & 10.41 & 16.76 & 12.46 & 17.39 \\
\hline & 50 & 14.10 & 18.72 & 14.94 & 18.24 & 12.13 & 17.74 & 16.76 & 18.19 \\
\hline & 100 & 15.54 & 19.15 & 16.81 & 18.55 & 12.93 & 18.05 & 19.00 & 18.45 \\
\hline \multirow{3}{*}{ WS5 } & 10 & 11.18 & 17.83 & 10.75 & 17.12 & 9.92 & 16.74 & 12.13 & 17.10 \\
\hline & 50 & 14.35 & 19.28 & 14.05 & 18.22 & 11.51 & 17.72 & 16.20 & 17.86 \\
\hline & 100 & 15.94 & 19.75 & 15.73 & 18.57 & 12.25 & 18.03 & 18.31 & 18.10 \\
\hline & 10 & 11.09 & 17.94 & 10.46 & 17.64 & 9.73 & 16.82 & 11.80 & 17.22 \\
\hline S1 & 50 & 14.47 & 19.54 & 13.63 & 18.94 & 11.28 & 17.79 & 15.64 & 18.16 \\
\hline & 100 & 16.20 & 20.06 & 15.24 & 19.36 & 12.00 & 18.10 & 17.62 & 18.46 \\
\hline & 10 & 10.96 & 18.13 & 10.13 & 17.96 & 9.56 & 16.85 & 11.52 & 17.57 \\
\hline S2 & 50 & 14.58 & 19.68 & 13.14 & 19.21 & 11.29 & 17.79 & 15.36 & 18.53 \\
\hline & 100 & 16.45 & 20.18 & 14.67 & 19.61 & 12.12 & 18.09 & 17.34 & 18.83 \\
\hline & 10 & 10.21 & 15.77 & 9.54 & 17.52 & 8.69 & 17.14 & 10.78 & 17.17 \\
\hline S3 & 50 & 13.72 & 16.47 & 12.58 & 18.94 & 10.31 & 18.17 & 14.58 & 18.12 \\
\hline & 100 & 15.55 & 16.69 & 14.14 & 19.40 & 11.09 & 18.50 & 16.57 & 18.42 \\
\hline & 10 & 9.03 & 15.57 & 8.87 & 17.17 & 7.83 & 16.93 & 9.74 & 17.33 \\
\hline S4 & 50 & 12.19 & 16.37 & 12.06 & 18.51 & 9.50 & 18.07 & 13.46 & 18.50 \\
\hline & 100 & 13.84 & 16.62 & 13.73 & 18.95 & 10.31 & 18.43 & 15.44 & 18.88 \\
\hline & 10 & 7.64 & 15.29 & 7.89 & 17.35 & 6.85 & 17.00 & 8.45 & 17.27 \\
\hline S5 & 50 & 10.40 & 16.01 & 11.27 & 19.22 & 8.66 & 18.70 & 12.06 & 18.59 \\
\hline & 100 & 11.85 & 16.24 & 13.11 & 19.84 & 9.56 & 19.25 & 14.02 & 19.01 \\
\hline
\end{tabular}




\subsubsection{Significant wave height}

Results obtained for different $\mathrm{H}_{\mathrm{s}}$ return periods (Table 11) show increasing values from 10- to 100-year, as expected. In general, the values of $\mathrm{H}_{\mathrm{s}}$ decrease from the northern to southern station groups in the sequence $\mathrm{WN}>\mathrm{N}>\mathrm{WS}>\mathrm{S}$, where values found for $\mathrm{S}$ are considerably lower (average from $67 \%$ to $77 \%$ ) than those of the remaining station groups.

For each station group, when HP data values are compared with the projected results from the RCPs scenarios for $\mathrm{H}_{\mathrm{s}}$, tendencies show that: (i) HP data values are slightly analogous than those calculated in the RCPs_mid; (ii) projected values obtained from RCPs_end have higher values when compared to HP data values, with special incidence of the results obtained from RCP8.5.

$\mathrm{H}_{\mathrm{s}}$ return values obtained from $\mathrm{RCP} 4.5 \_\mathrm{mid}$ and $\mathrm{RCP} 4.5$ _end are apparently contradictory, since results are mostly lower for RCP4.5_end than for RCP4.5_mid. However, similar results can also be found in Copernicus Climate Change Service (2019) for the Iberian Peninsula. This is not the case with the RCP8.5 scenarios, where the return values from RCP8.5_end are consistently higher than those from RCP8.5_mid.

Table 11. Return values for $H_{s}(m)$.

\begin{tabular}{ccccccc}
\hline \multirow{2}{*}{$\begin{array}{c}\text { Return } \\
\text { period } \\
\text { (years) }\end{array}$} & $\begin{array}{c}\text { Station } \\
\text { Group }\end{array}$ & HP & RCP4.5_mid & RCP4.5_end & RCP8.5_mid & RCP8.5_end \\
\cline { 2 - 7 } & $\mathbf{N}$ & $12.19-13.12$ & $13.36-14.62$ & $11.80-13.66$ & $12.12-13.18$ & $13.23-15.96$ \\
\cline { 2 - 7 } $\mathbf{1 0}$ & $\mathbf{W N}$ & $12.36-13.38$ & $12.42-14.67$ & $13.49-14.15$ & $12.27-13.32$ & $15.10-16.32$ \\
\cline { 2 - 7 } & $\mathbf{W S}$ & $10.79-12.10$ & $11.18-12.19$ & $10.75-13.12$ & $9.92-10.80$ & $12.13-13.68$ \\
\cline { 2 - 7 } & $\mathbf{S}$ & $7.56-10.40$ & $7.64-11.09$ & $7.89-10.46$ & $6.85-9.73$ & $8.45-11.80$ \\
\hline \multirow{3}{*}{$\mathbf{5 0}$} & $\mathbf{N}$ & $15.12-16.12$ & $18.28-19.42$ & $14.44-17.47$ & $15.71-17.05$ & $17.63-22.64$ \\
\cline { 2 - 7 } & $\mathbf{W N}$ & $15.28-16.53$ & $15.76-19.47$ & $17.74-18.80$ & $15.12-17.26$ & $20.76-23.14$ \\
\hline \multirow{2}{*}{$\mathbf{1 0 0}$} & $\mathbf{W S}$ & $13.27-14.94$ & $14.10-15.69$ & $14.05-17.69$ & $11.51-12.34$ & $16.20-18.19$ \\
\hline & $\mathbf{S}$ & $9.93-12.64$ & $10.40-14.58$ & $11.27-13.63$ & $8.66-11.29$ & $12.06-15.64$ \\
\hline & $\mathbf{N}$ & $16.57-17.58$ & $20.87-21.90$ & $15.73-19.39$ & $17.53-19.01$ & $19.90-26.25$ \\
\hline & $\mathbf{W N}$ & $16.71-18.08$ & $17.44-21.94$ & $19.66-21.31$ & $16.51-19.26$ & $23.75-26.81$ \\
\hline & $\mathbf{W S}$ & $14.48-16.34$ & $15.54-17.46$ & $15.73-20.07$ & $12.25-13.06$ & $18.31-20.53$ \\
\hline
\end{tabular}

\subsubsection{Wave peak period}

For each return period, wave peak period $\mathrm{T}_{\mathrm{p}}$ (Table 12) appears to maintain constant values in all station groups, independently the scenario considered. Approximate values of 17,50 s, 18,00 s, and 19,00 s have been obtained for 10-, 50-, 100-year return period, respectively. 
Table 12. Return values for $T_{p}(s)$.

\begin{tabular}{ccccccc}
\hline \multirow{2}{*}{$\begin{array}{c}\text { Return } \\
\text { period } \\
\text { (years) }\end{array}$} & $\begin{array}{c}\text { Station } \\
\text { Group }\end{array}$ & \multicolumn{6}{c}{ Wave climate regime scenario } \\
\cline { 2 - 7 } & HP & RCP4.5_mid & RCP4.5_end & RCP8.5_mid & RCP8.5_end \\
\cline { 2 - 7 } $\mathbf{1 0}$ & $\mathbf{N}$ & $17.73-18.13$ & $17.79-18.01$ & $16.90-17.38$ & $17.62-18.02$ & $17.23-17.62$ \\
\cline { 2 - 7 } & $\mathbf{W N}$ & $17.53-18.18$ & $17.90-18.20$ & $16.65-17.18$ & $17.39-17.77$ & $17.19-17.63$ \\
\cline { 2 - 7 } & $\mathbf{W S}$ & $17.60-18.12$ & $17.36-18.76$ & $17.02-17.26$ & $16.70-17.13$ & $16.97-17.39$ \\
\cline { 2 - 7 } & $\mathbf{S}$ & $16.56-18.20$ & $15.29-18.13$ & $17.17-17.96$ & $16.82-17.14$ & $17.17-17.57$ \\
\hline \multirow{3}{*}{$\mathbf{5 0}$} & $\mathbf{N}$ & $18.68-19.05$ & $18.97-19.20$ & $17.81-18.50$ & $18.77-19.18$ & $17.95-18.61$ \\
\cline { 2 - 7 } & $\mathbf{W N}$ & $18.47-19.25$ & $19.16-19.39$ & $17.41-18.00$ & $18.45-18.94$ & $17.87-18.49$ \\
\cline { 2 - 7 } & $\mathbf{W S}$ & $18.51-19.15$ & $18.72-20.30$ & $17.79-18.24$ & $17.56-18.15$ & $17.74-18.19$ \\
\hline \multirow{3}{*}{$\mathbf{1 0 0}$} & $\mathbf{S}$ & $17.92-19.33$ & $16.01-19.68$ & $18.51-19.22$ & $17.79-18.70$ & $18.12-18.59$ \\
\cline { 2 - 7 } & $\mathbf{N}$ & $18.99-19.35$ & $19.31-19.58$ & $18.11-18.86$ & $19.14-19.56$ & $18.18-18.93$ \\
\cline { 2 - 7 } & $\mathbf{W N}$ & $18.77-19.60$ & $19.56-19.82$ & $17.66-18.26$ & $18.79-19.32$ & $18.09-18.76$ \\
\cline { 2 - 7 } & $\mathbf{W S}$ & $18.80-19.48$ & $19.15-20.80$ & $18.03-18.57$ & $17.83-18.48$ & $17.98-18.45$ \\
\hline & $\mathbf{S}$ & $18.36-19.70$ & $16.24-20.18$ & $18.95-19.84$ & $18.09-19.25$ & $18.42-19.01$ \\
\hline
\end{tabular}

\subsection{Comparison with existing studies}

Two studies (Carvalho and Capitão, 1995 and Capitão and Fortes, 2011) were carried out to estimate 10-, 50-, 100-year return period of $\mathrm{H}_{\mathrm{s}}$ at three sites on the western coast of Portugal (Leixões, Figueira da Foz and Sines). These studies differ partly in their research approach and scope from the present one, but are anyway useful benchmark to test the validity of the obtained results.

The main important difference is that the present study uses an extensive modelled dataset consisting of 46 years of historical data and two twenty-year time periods of RCPs projected data applied at 17 locations far from the coast, whereas in the other studies the wave data have been recorded for 13 years in the harbours of Figueira da Foz and Sines (Carvalho and Capitão, 1995) and 14 years in Leixões (Capitão and Fortes, 2011).

Table 13 compares the $\mathrm{H}_{\mathrm{s}}$ extremes values predictions of this study for the HP scenario against those obtained in the other two studies. Stations WN3, WS1 and WS3 were considered geographically near to Leixões, Figueira da Foz and Sines, respectively. The comparison between the results obtained in the present study and in Carvalho and Capitão (1995) shows small differences. However, large discrepancies were found when the comparison is made with Capitão and Fortes (2011). The discrepancies found can be justified for three main reasons: (i) the temporal and spatial dimensions of data sources; (ii) the fact that a storm sub-dataset extracted from the wave dataset was used in the calculation of extreme values in the present study; and (iii) the wave climate data near the coast (as used by those authors) is influenced by wave refraction due to local bathymetric characteristics. 
Table 13. Estimate values of $\mathrm{H}_{\mathrm{s}}$ on the western coast of Portugal obtained in different studies.

\begin{tabular}{|c|c|c|c|c|}
\hline \multirow[b]{2}{*}{ Location } & \multirow[b]{2}{*}{$\mathbf{T}_{\mathbf{r}}($ years $)$} & \multicolumn{3}{|c|}{ Extreme values of $\mathrm{H}_{\mathrm{s}}(\mathrm{m})$} \\
\hline & & Present study (HP data) & $\begin{array}{l}\text { (Carvalho and } \\
\text { Capitão, 1995) }\end{array}$ & $\begin{array}{l}\text { (Capitão and } \\
\text { Fortes, 2011) }\end{array}$ \\
\hline \multirow{3}{*}{$\begin{array}{c}\text { WN3 } \\
\text { Leixões }\end{array}$} & 10 & 12.69 & - & 7.25 \\
\hline & 50 & 15.59 & - & 9.62 \\
\hline & 100 & 17.01 & - & 10.84 \\
\hline \multirow{3}{*}{$\begin{array}{c}\text { WS1 } \\
\text { Figueira da } \\
\text { Foz }\end{array}$} & 10 & 12.14 & 10.60 & - \\
\hline & 50 & 14.36 & 12.80 & - \\
\hline & 100 & 15.31 & 13.80 & - \\
\hline \multirow{3}{*}{$\begin{array}{l}\text { WS3 } \\
\text { Sines }\end{array}$} & 10 & 11.43 & 10.70 & - \\
\hline & 50 & 14.10 & 15.80 & - \\
\hline & 100 & 15.41 & 18.20 & - \\
\hline
\end{tabular}

\subsection{Extreme values for coastal engineering design}

The results obtained in this study for 100-year return values of $\mathrm{H}_{\mathrm{s}}$ and $\mathrm{T}_{\mathrm{p}}$ derived for HP data and RCP8.5_end in four station groups are summarized in Table 14. The methodology followed for extreme value analysis based on a storm sub-dataset obtained from the $\mathrm{H}_{\mathrm{s}} 95^{\text {th }}$ percentile of original wave datasets justifies the higher estimated values for 100-year $\mathrm{H}_{\mathrm{s}}$ from the RCP8.5_end scenario when compared to the one estimated for HP data. The obtained results are aligned with other similar works (e.g., Copernicus Climate Change Service (2019)) that project more intense extreme $\mathrm{H}_{\mathrm{s}}$ for the end of the century.

Awareness on the prediction of 100-year return values from RCP scenarios should be taken, since these scenarios are based on uncertainty and a 20-year span data. However, the obtained results are robust and can be of valuable interest in engineering practice.

These values can be used as design parameters in maritime structures projects to be applied in the Iberian Peninsula coastal zone, once propagated to the local of interest by appropriate methodologies.

Table 14. 100-year return period values for $H_{s}$ and $T_{p}$ as parameters for structural engineering design.

\begin{tabular}{cccccc}
\hline \multirow{2}{*}{ Wave data } & \multicolumn{4}{c}{ Station Group } \\
\cline { 2 - 6 } & & $\mathbf{N}$ & WN & WS & S \\
\hline \multirow{2}{*}{ HP data } & $\mathbf{H}_{\mathbf{s}}(\mathbf{m})$ & $16.57-17.58$ & $16.71-18.08$ & $14.48-16.34$ & $11.14-13.73$ \\
\cline { 2 - 6 } & $\mathbf{T}_{\mathbf{p}}(\mathbf{s})$ & $18.99-19.35$ & $18.77-19.60$ & $18.80-19.48$ & $18.36-19.70$ \\
\hline \multirow{2}{*}{ RCP8.5_end } & $\mathbf{H}_{\mathbf{s}}(\mathbf{m})$ & $19.90-26.25$ & $23.75-26.81$ & $18.31-20.53$ & $14.02-17.62$ \\
\cline { 2 - 6 } & $\mathbf{T}_{\mathbf{p}}(\mathbf{s})$ & $18.18-18.93$ & $18.09-18.76$ & $17.98-18.45$ & $18.42-19.01$ \\
\hline
\end{tabular}

\section{Conclusions}

The present study developed an extreme wave value analysis under uncertainty scenarios using comprehensive simulated wave datasets downscaled by Meteogalicia from CMIP5 models to 17 stations off the Iberian Peninsula coastal zone.

The extreme wave data values for $\mathrm{H}_{\mathrm{s}}$ and $\mathrm{T}_{\mathrm{p}}$ were calculated through the Gumbel, Fréchet and Weibull distributions for the 10-, 50-, and 100-year return period. Five wave climate scenarios using HP data and projected data of RCP4.5_mid, RCP4.5_end, RCP8.5_mid and RCP8.5_end were considered. 
Descriptive statistical analysis of the obtained wave results demonstrated that: (i) $\mathrm{H}_{\mathrm{s}}$ has different values at different locations in the coastal zone with decreasing values from North to South; (ii) HP data values are higher than those calculated in any of the RCPs scenarios; (iii) projected $\mathrm{H}_{\mathrm{s}}$ values obtained from RCP4.5 and RCP8.5 have slight differences (approximately $4 \%$ ) between these considered scenarios; (iv) maximum $\mathrm{H}_{\mathrm{s}}$ values show contradictory tendencies when HP data are compared to projected data; (v) maximum values of $\mathrm{H}_{\mathrm{s}}$ obtained for RCP4.5_mid and RCP8.5_end scenarios are higher than those of the HP data for the northern stations and lower for the southern stations; (vi) mean $T_{p}$ appears to maintain constant values in all stations, independently the wave climate regime scenario considered; (vii) results for mean $D_{m}$ and mean $D_{p}$ show higher frequency of occurrence in $\mathrm{Q} 4\left(270^{\circ}-360^{\circ}\right)$ followed by a smaller frequency in Q3 $\left(180^{\circ}-270^{\circ}\right)$.

Extreme $\mathrm{H}_{\mathrm{s}}$ values for all return periods have different values in different locations in the coastal zone with decreasing values from North to South, being considerably lower on the most southern stations. In each station, HP data values are similar to those calculated in the RCPs_mid, and projected values obtained from the RCPs_end have higher values when compared to HP data values. For each return period, wave peak period $\mathrm{T}_{\mathrm{p}}$ results show constant values in all stations, independently the scenario considered.

Wave extreme value analysis for the $\mathrm{H}_{\mathrm{s}}$ and $\mathrm{T}_{\mathrm{p}}$ is an essential element for marine structural design. The high-quality of the database applied and the assumptions taken in this research work allowed the determination of 100-year return period of $\mathrm{H}_{\mathrm{s}}$ and $\mathrm{T}_{\mathrm{p}}$ values that can be used with confidence as design values for structural analyses in maritime works to be built in the western coast off Iberian Peninsula.

\section{Acknowledgements}

The authors acknowledge the financial support provided by the Portuguese Foundation for Science and Technology (FCT), PhD grant number SFRH/BD/141381/2018. This research was also partially supported by the 0262_MarRISK_1_E project funded by Interreg V-A Spain-Portugal Program (POCTEP).

\section{Author contributions}

Bárbara Vieira: Conceptualization, Methodology, Validation, Formal analysis, Investigation, Resources, Writing — original draft preparation, Writing — review and editing, Visualization.

José Pinho: Conceptualization, Methodology, Validation, Formal analysis, Investigation, Resources, Writing — review and editing, Visualization, Supervision.

Joaquim Barros: Conceptualization, Methodology, Validation, Formal analysis, Writing —review and editing, Visualization, Supervision.

\section{References}


Álvarez, F., Pan, S., Coelho, C., Baptista, P., 2020. Modeling Shoreline Changes in Northwest Portugal Using a Process-Based Numerical Model: COAST2D. J. Waterw. Port, Coastal, Ocean Eng. 146. https://doi.org/10.1061/(ASCE)WW.1943-5460.0000563.

Baptista, P., Coelho, C., Pereira, C., Bernardes, C., Veloso-Gomes, F., 2014. Beach morphology and shoreline evolution: Monitoring and modelling medium-term responses (Portuguese NW coast study site). Coast. Eng. 84, 23-37. https://doi.org/https://doi.org/10.1016/j.coastaleng.2013.11.002.

Bio, A., Gonçalves, J.A., Pinho, J., Vieira, L., Vieira, J., Smirnov, G., Bastos, L., 2020. Indicadores de vulnerabilidade de erosão costeira: Um estudo de caso no Norte de Portugal. Rev. Gestão Costeira Integr. - J. Integr. Coast. Zo. Manag. 20, 197-209. https://doi.org/10.5894/rgci-n337.

Callaghan, D.P., Wainwright, D.J., Hanslow, D.J., 2020. Consideration of uncertainty in sea level rise in Australia's most exposed estuary: A discussion on allowances under different epistemic uncertainties. Coast. Eng. 159, 103718. https://doi.org/https://doi.org/10.1016/j.coastaleng.2020.103718.

Capitão, R., Fortes, C., 2011. A variabilidade das extrapolações do regime de extremos com a natureza das amostras: o caso de estudo do porto de vila do conde, in: 7as Jornadas Portuguesas de Engenharia Costeira E Portuária, 6 E 7 de Outubro de 2011. Porto, Portugal, p. 16.

Carvalho, M., Capitão, R., 1995. Extreme wave heights off the western coast of Portugal, in: Proceedings of the 14th International Conference on Offshore Mechanics and Arctic Engineering, 18th to 22th June 1995. Copenhagen, Denmark.

Castelle, B., Marieu, V., Bujan, S., Splinter, K.D., Robinet, A., Sénéchal, N., Ferreira, S., 2015. Impact of the winter 2013-2014 series of severe Western Europe storms on a double-barred sandy coast: Beach and dune erosion and megacusp embayments. Geomorphology 238, 135-148. https://doi.org/https://doi.org/10.1016/j.geomorph.2015.03.006.

Cheng, H.-Q., Chen, J.-Y., 2017. Adapting cities to sea level rise: A perspective from Chinese deltas. Adv. Clim. Chang. Res. 8, 130-136. https://doi.org/https://doi.org/10.1016/j.accre.2017.05.006.

Cherneva, Z., Petrova, P., Andreeva, N., Guedes-Soares, C., 2005. Probability distributions of peaks, troughs and heights of wind waves measured in the black sea coastal zone. Coast. Eng. 52, 599615. https://doi.org/https://doi.org/10.1016/j.coastaleng.2005.02.006.

Chini, N., Stansby, P., Leake, J., Wolf, J., Roberts-Jones, J., Lowe, J., 2010. The impact of sea level rise and climate change on inshore wave climate: A case study for East Anglia (UK). Coast. Eng. 57, 973-984. https://doi.org/https://doi.org/10.1016/j.coastaleng.2010.05.009.

Copernicus Climate Change Service, 2019. ECMWF Copernicus Report: Product user guide for sea level and ocean wave products - time series and indicators. C3S_422_Lot2_Deltares - European Services.

Cotta, H., Correa, W., Albuquerque, T., 2016. Aplicação da distribuição de Gumbel para valores extremos de precipitação no município de Vitória-ES.

Dentale, F., Furcolo, P., Carratelli, E.P., Reale, F., Contestabile, P., Tomasicchio, G.R., 2018. Extreme Wave Analysis by Integrating Model and Wave Buoy Data. Water (Switzerland) 10. https://doi.org/10.3390/w10040373.

Ding, Y., Nath Kuiry, S., Elgohry, M., Jia, Y., Altinakar, M.S., Yeh, K.-C., 2013. Impact assessment of sea-level rise and hazardous storms on coasts and estuaries using integrated processes model. Ocean Eng. 71, 74-95. https://doi.org/https://doi.org/10.1016/j.oceaneng.2013.01.015.

Feng, J., Wen-Shan, L., Hui, W., Jian-Li, Z., Jun-Xing, D., 2019. Evaluation of sea level rise and associated responses in Hangzhou Bay from 1978 to 2017. Adv. Clim. Chang. Res. 9. https://doi.org/10.1016/j.accre.2019.01.002.

Filliben, J.J., 1975. The Probability Plot Correlation Coefficient Test for Normality. Technometrics 17, 111-117. https://doi.org/10.1080/00401706.1975.10489279.

Goda, Y., 2000. Statistical Analysis of Extreme Waves, in: Liu, P.L.-F. (Ed.), Random Seas and Design of Maritime Structures, Volume 15. World Scientific Publishing Co. Pte. Ltd., Singapore, pp. $377-$ 425.

Gomes, M., Santos, L., Pinho, J., Antunes do Carmo, J., 2018. Hazard Assessment of Storm Events for the Portuguese Northern Coast. Geosciences 8, 178. https://doi.org/10.3390/geosciences8050178. 
Guedes-Soares, C., Carvalho, A., 2001. Probability Distributions of Wave Heights and Periods in Measured Two-Peaked Spectra from the Portuguese Coast, in: Proceedings of the 20th International Conference on Offshore Mechanics and Arctic Engineering, 3rd to 8th June 2001. Rio de Janeiro, Brazil.

Harley, M., 2017. Coastal Storm Definition, in: Coco, G., Ciavola, P. (Eds.), Coastal Storms: Processes and Impacts. Wiley-Blackwell, pp. 1-22. https://doi.org/10.1002/9781118937099.ch1.

IPCC, 2020. Scenario Process for AR5 - Representative Concentration Pathways (RCPs) [WWW Document]. URL https://sedac.ciesin.columbia.edu/ddc/ar5_scenario_process/RCPs.html. (accessed 5.12.20)

IPCC, 2014. Climate Change 2014: Synthesis Report. Contribution of Working Groups I, II and III to the Fifth Assessment Report of the Intergovernmental Panel on Climate Change [Core Writing Team]. Geneva, Switzerland.

Karian, Z.A., Dudewicz, E.J., 2000. Fitting statistical distributions: The generalized lambda distribution and generalized bootstrap methods, Fitting Statistical Distributions: The Generalized Lambda Distribution and Generalized Bootstrap Methods.

Lyu, K., Zhang, X., Church, J.A., 2020. Regional Dynamic Sea Level Simulated in the CMIP5 and CMIP6 Models: Mean Biases, Future Projections, and Their Linkages. J. Clim. 33, 6377-6398. https://doi.org/10.1175/JCLI-D-19-1029.1.

Marone, E., Camargo, R. de, Castro, J.S., 2017. Coastal Hazards, Risks, and Marine Extreme Events. Oxford Handbooks Online Coast. 1-19. https://doi.org/10.1093/oxfordhb/9780190699420.013.34.

Martucci, G., Carniel, S., Chiggiato, J., Sclavo, M., Lionello, P., Galati, M.B., 2010. Statistical trend analysis and extreme distribution of significant wave height from 1958 to 1999 - an application to the Italian Seas. Ocean Sci. 6, 525-538. https://doi.org/10.5194/os-6-525-2010.

Mase, H., Tsujio, D., Yasuda, T., Mori, N., 2013. Stability analysis of composite breakwater with wavedissipating blocks considering increase in sea levels, surges and waves due to climate change. Ocean Eng. 71, 58-65. https://doi.org/https://doi.org/10.1016/j.oceaneng.2012.12.037.

Masselink, G., Austin, M., Scott, T., Poate, T., Russell, P., 2014. Role of wave forcing, storms and NAO in outer bar dynamics on a high-energy, macro-tidal beach. Geomorphology 226, 76-93. https://doi.org/https://doi.org/10.1016/j.geomorph.2014.07.025.

Mathiesen, M., Goda, Y., Hawkes, P.J., Mansard, E., Martín, M.J., Peltier, E., Thompson, E.F., Van Vledder, G., 1994. Recommended practice for extreme wave analysis. J. Hydraul. Res. 32, $803-$ 814. https://doi.org/10.1080/00221689409498691.

McKenna, S., Santoso, A., Gupta, A. Sen, Taschetto, A.S., Cai, W., 2020. Indian Ocean Dipole in CMIP5 and CMIP6: characteristics, biases, and links to ENSO. Sci. Rep. 10, 11500. https://doi.org/10.1038/s41598-020-68268-9.

Merkens, J.-L., Reimann, L., Hinkel, J., Vafeidis, A.T., 2016. Gridded population projections for the coastal zone under the Shared Socioeconomic Pathways. Glob. Planet. Change 145, 57-66. https://doi.org/https://doi.org/10.1016/j.gloplacha.2016.08.009.

Milly, P.C.D., Betancourt, J., Falkenmark, M., Hirsch, R.M., Kundzewicz, Z.W., Lettenmaier, D.P., Stouffer, R.J., 2008. Stationarity Is Dead: Whither Water Management? Science (80-. ). 319, 573 LP-574. https://doi.org/10.1126/science.1151915.

Montanari, A., Koutsoyiannis, D., 2014. Modeling and mitigating natural hazards: Stationarity is immortal! Water Resour. Res. 50, 9748-9756. https://doi.org/10.1002/2014WR016092.

Mori, N., Shimura, T., Yasuda, T., Mase, H., 2013. Multi-model climate projections of ocean surface variables under different climate scenarios-Future change of waves, sea level and wind. Ocean Eng. 71, 122-129. https://doi.org/https://doi.org/10.1016/j.oceaneng.2013.02.016.

Morim, J., Hemer, M., Wang, X.L., Cartwright, N., Trenham, C., Semedo, A., Young, I., Bricheno, L., Camus, P., Casas-Prat, M., Erikson, L., Mentaschi, L., Mori, N., Shimura, T., Timmermans, B., Aarnes, O., Breivik, Ø., Behrens, A., Dobrynin, M., Menendez, M., Staneva, J., Wehner, M., Wolf, J., Kamranzad, B., Webb, A., Stopa, J., Andutta, F., 2019. Robustness and uncertainties in global multivariate wind-wave climate projections. Nat. Clim. Chang. 9, 711-718. https://doi.org/10.1038/s41558-019-0542-5. 
Naghettini, M., Pinto, É.J. de A., 2007. Análise local de frequência de variáveis hidrológicas, in: Hidrologia Estatística. CPRM.

Nascimento, L., 2009. Análise de Valores Extremos de Parâmetros de Resposta Dinâmica de Plataformas Auto-Elevatórias. MSc Thesis in Civil Engineering, Federal University of Rio de Janeiro, Brazil. https://doi.org/10.13140/RG.2.2.28024.85764.

Neumann, B., Vafeidis, A.T., Zimmermann, J., Nicholls, R.J., 2015. Future coastal population growth and exposure to sea-level rise and coastal flooding-a global assessment. PLoS One 10, e0118571.

Park, S.B., Shin, S.Y., Shin, D.G., Jung, K.H., Choi, Y.H., Lee, J., Lee, S.J., 2020. Extreme Value Analysis of Metocean Data for Barents Sea. J. Ocean Eng. Technol. 34, 26-36. https://doi.org/10.26748/KSOE.2019.094.

Pereira, C., Coelho, C., 2013. Mapping erosion risk under different scenarios of climate change for Aveiro coast, Portugal. Nat. Hazards 69, 1033-1050. https://doi.org/10.1007/s11069-013-0748-1.

Piccinini, F., 2006. A onda de projeto por meio de análise estatística de extremos a partir de dados medidos por satélite. Rev. Pesqui. Nav. 84-90.

Pinho, J., Vieira, L., Vieira, J., Smirnov, G., Gomes, A., Bio, A., Gonçalves, J.A., Bastos, L., 2020. Modelação da hidrodinâmica e da morfodinâmica na costa Noroeste de Portugal em cenários de alterações climáticas. J. Integr. Coast. Zo. Manag. / Rev. Gestão Costeira Integr. 20, 89-102. https://doi.org/10.5894/rgci-n297.

Plecha, S.M., Soares, P.M.M., 2020. Global Marine Heatwave events using the new CMIP6 multi-model ensemble: from shortcomings in present climate to future projections. Environ. Res. Lett.

Qu, Y., Liu, Y., Jevrejeva, S., Jackson, L.P., 2020. Future sea level rise along the coast of China and adjacent region under $1.5^{\circ} \mathrm{C}$ and $2.0^{\circ} \mathrm{C}$ global warming. Adv. Clim. Chang. Res. https://doi.org/https://doi.org/10.1016/j.accre.2020.09.001.

Reale, F., Dentale, F., Furcolo, P., Di Leo, A., Carratelli, E.P., 2020. An Experimental Assessment of Extreme Wave Evaluation by Integrating Model and Wave Buoy Data. Water (Switzerland) 12. https://doi.org/10.3390/w12041201.

Sansigolo, C.A., 2008. Distribuições de extremos de precipitação diária, temperatura máxima e mínima e velocidade do vento em Piracicaba, SP (1917-2006). Rev. Bras. Meteorol. 23, 341-346. https://doi.org/doi.org/10.1590/S0102-77862008000300009.

Santos, L., Gomes, M., Vieira, L., Pinho, J., Antunes do Carmo, J., 2018. Storm surge assessment methodology based on numerical modelling, in: Loggia, G. La, Freni, G., Puleo, V., Marchis, M. De (Eds.), HIC 2018 EPiC Series in Engineering, Volume 3. pp. 1876-1884. https://doi.org/10.29007/hrlw.

Silva, R., Coelho, C., Veloso-Gomes, F., Taveira-Pinto, F., 2008. A importância de alguns parâmetros hidromorfológicos em estudos de modelação na zona costeira (The importance of some hydromorphological parameters in coastal zones modeling studies), in: Jornadas de Hidráulica, Recursos Hídricos E Ambiente. Faculdade de Engenharia Da Universidade Do Porto. pp. 25-35.

Sperna-Weiland, F.C., Hegnauer, M., Boogaard, H. Van den, Buiteveld, H., Lammersen, R., Beersma, J., 2016. Implications of CMIP5 derived climate scenarios for discharge extremes of the Rhine, in: Erpicum, S., Dewals, B., Archambeau, P., Pirotton, M. (Eds.), Proceedings of the 4th IAHR Europe Congress (Liege, Belgium, 27-29 July 2016). Sustainable Hydraulics in the Era of Global Change: Hydrometeorological Extremes, Uncertainties and Global Change. CRC Press, London, UK, pp. 790-795. https://doi.org/doi.org/10.1201/b21902.

SROCC, 2019. IPCC SR Ocean and Cryosphere Sea Level Rise and Implications for Low Lying Islands, Coasts and Communities - Chapter 4, Final Draft. p. 31.

Sun, Q.-H., Xia, J., Miao, C.-Y., Duan, Q.-Y., 2017. Bayesian multi-model projections of extreme hydroclimatic events under RCPs scenarios. Adv. Clim. Chang. Res. 8, 80-92. https://doi.org/https://doi.org/10.1016/j.accre.2017.06.001.

Tatebe, H., Ishii, M., Mochizuki, T., Chikamoto, Y., Sakamoto, T.T., Komuro, Y., Mori, M., Yasunaka, S., Watanabe, M., Ogochi, K., Suzuki, T., Nishimura, T., Kimoto, M., 2012. The Initialization of the MIROC Climate Models with Hydrographic Data Assimilation for Decadal Prediction. J. Meteorol. Soc. Japan. Ser. II 90A, 275-294. https://doi.org/10.2151/jmsj.2012-A14. 
Thevasiyani, T., Perera, K., 2014. Statistical analysis of extreme ocean waves in Galle, Sri Lanka. Weather Clim. Extrem. 5-6, 40-47. https://doi.org/https://doi.org/10.1016/j.wace.2014.07.003.

Urošev, M., Leš cešen, I., Štrbac, D., Dolinaj, D., 2016. Extreme hydrological situations on Danube River - Case study Bezdan hydrological station (Serbia), in: Erpicum, S., Dewals, B., Archambeau, P., Pirotton, M. (Eds.), Proceedings of the 4th IAHR Europe Congress (Liege, Belgium, 27-29 July 2016). Sustainable Hydraulics in the Era of Global Change: Hydrometeorological Extremes, Uncertainties and Global Change. CRC Press, London, UK, pp. 771-778. https://doi.org/doi.org/10.1201/b21902.

Vanem, E., 2017. A regional extreme value analysis of ocean waves in a changing climate. Ocean Eng. 144, 277-295. https://doi.org/https://doi.org/10.1016/j.oceaneng.2017.08.027.

Vanem, E., 2015. Uncertainties in extreme value modelling of wave data in a climate change perspective. J. Ocean Eng. Mar. Energy 1, 339-359. https://doi.org/10.1007/s40722-015-0025-3.

Vivekanandan, N., 2012. Comparison of Estimators of Extreme Value Distributions for Wind Data Analysis. Bonfring Int. J. Data Min. 2, 16-20. https://doi.org/10.9756/BIJDM.1503.

Wang, L., Chen, B., Zhang, J., Chen, Z., 2013. A new model for calculating the design wave height in typhoon-affected sea areas. Nat. Hazards 67, 129-143. https://doi.org/10.1007/s11069-012-0266-6.

Wang, X., Feng, Y., Swail, V.R., 2016. Projected changes, climate change signal, and uncertainties in the CMIP5-based projections of ocean surface wave heights, in: EGU General Assembly 2016, 17th to 22nd April 2016. Vienna, Austria.

Wang, X., Swail, V.R., 2001. Changes of Extreme Wave Heights in Northern Hemisphere Oceans and Related Atmospheric Circulation Regimes. J. Clim. 14, 2204-2221. https://doi.org/10.1175/15200442(2001)014<2204:COEWHI>2.0.CO;2.

Warner, N.N., Tissot, P.E., 2012. Storm flooding sensitivity to sea level rise for Galveston Bay, Texas. Ocean Eng. 44, 23-32. https://doi.org/https://doi.org/10.1016/j.oceaneng.2012.01.011.

Winterstein, S.R., Ude, T.C., Cornell, C.A., Bjerager, P., Haver, S., 1993. Environmental parameters for extreme response: Inverse FORM with omission factors, in: Proceedings of the 6th International Conference on Structural Safety and Reliability (ICOSSAR-93), 9th to 13th August 1993. Innsbruck, Austria.

WMO, 1998. Guide to wave analysis and forecasting - 2nd edition, WMO-No. 702. Geneva, Switzerland.

Xie, D., Zou, Q.-P., Mignone, A., MacRae, J.D., 2019. Coastal flooding from wave overtopping and sea level rise adaptation in the northeastern USA. Coast. Eng. 150, 39-58. https://doi.org/https://doi.org/10.1016/j.coastaleng.2019.02.001.

Zhang, K., Douglas, B.C., Leatherman, S.P., 2004. Global Warming and Coastal Erosion. Clim. Change 64, 41. https://doi.org/10.1023/B:CLIM.0000024690.32682.48.

Zhu, H., Jiang, Z., Li, J., Li, W., Sun, C., Li, L., 2020. Does CMIP6 Inspire More Confidence in Simulating Climate Extremes over China? Adv. Atmos. Sci. 37, 1119-1132. https://doi.org/10.1007/s00376-020-9289-1. 